\title{
Cointegration Analysis among the Variables of the Ohlson Model for Brazilian Companies
}

\author{
Júlio Pereira de Araújo $^{1}$, Marcos Roberto Gois de Oliveira Macedo ${ }^{1}$ \\ ${ }^{1}$ Federal University of Pernambuco, Pernambuco, Brazil \\ Correspondence: Júlio Pereira de Araújo, Federal University of Pernambuco, Pernambuco, Brazil.
}

Received: January 8, 2018

doi:10.11114/afa.v4i1.2969
Accepted: January 29, 2018

Available online: January 30, 2018

URL: https://doi.org/10.11114/afa.v4i1.2969

\begin{abstract}
We examine whether there is a long-term equilibrium relation between the companies market value and the variables accounting book value and abnormal earnings based on the Ohlson model (1995) using a cointegration approach. Our panel cointegration analysis indicates that the variables cointegrate when using the whole sample, the most liquid companies group and for all sectors in at least one of the tests performed with exception of the Telecommunications sector, which presented no cointegration in both tests. The time series cointegration results have shown that, except for one company, for all the remaining the variables cointegrated. Therefore, the Ohlson Model (1995) is relevant for the evaluation of Brazilian listed companies in a long-term equilibrium. In addition, we provide evidence that abnormal earnings have limited explanatory power compared to book value.
\end{abstract}

Keywords: Ohlson model, panel cointegration, time series cointegration

\section{Introduction}

Any company that generates useful, scarce and timely goods and services - in other words value holders - can be evaluated. This evaluation aims to reach the fair market value for the company, meaning an amount that represents, in a balanced way, its economic potential related to the net benefits that it is expected to produce in the present and in the future (Miranda, Reis \& Lemes, 2006).

In this way, capital market participants are always looking for value stocks and a valid valuation method that will take them to the value inherent in the stock. Among the factors that can influence stock prices, the information in the financial statements plays an important role. Since this source of information is mandatory, with a high degree of quantification and standardization, the interest of investors and the sensitivity to their disclosure are considerable. For example, the various studies that have been conducted to predict stock prices have shown an increase in the role of book value in stock valuation and in the relationship of this variable to the market value of firms (Dung, 2010; Etemadi \& Mougouie, 2015).

Since the publication of Ball and Brown's first study of this subject, in 1968, until 1995, there have been many attempts, mainly empirical, to measure the relevance of the information value of financial statements. However, an important common feature of all these studies is the lack of a sound theoretical basis, since satisfactory answers to two essential questions have not been provided: (i) what information in the financial statements has a direct relation to stock prices?; and (ii) what is the theoretical model that measures this value-relevance? (Dung, 2010). In a research paper published in 1995, James Ohlson was able to answer these questions with a sound theoretical basis and his results strongly influenced the studies on the value-relevance of the information of the financial statements (Dung, 2010).

The Ohlson model (1995) is derived from discounted cash flow methods, which seek to determine the firm's value by estimating the cash flows that will be generated in the future and then discounting them at an appropriate discount rate (Fernandez, 2013). More specifically, Ohlson (1995) has shown that the firm's inherent value is equal to the book value of equity plus the present value of future abnormal earnings, plus a scalar variable representing "other information". His model has been extensively studied because of its importance both in evaluating the current stock price and in forecasting its future price (Lee, Chen \& Tsa, 2014).

Thus, the main contribution of the Ohlson Model is to provide as a theoretical framework a work for the valuation of stocks based on the fundamental variables of accounting (earnings and book value). In addition, allowing any other 
information to interfere with the company's value forecast (Etemadi \& Mougouie, 2015). Ohlson (1995) suggests that such "other information" in the model should be thought of as summarizing value-relevant events that have not yet had an impact on the financial statements. They refer to future (abnormal) earnings that are independent of current and past (abnormal) earnings. In other words, "other information" captures all non-accounting information that will eventually be reflected in future abnormal profits (Lee, Lin \& Yu, 2012).

There are several attempts to identify the "other information" variable. They include consensus analysts' predictions about next year's profits (Dechow, Hutton \& Sloan (1999)); dividends (Hand \& Landsman (1998)); rents and cash flows (Barth, Beaver, Hand \& Landsman (1999)), etc. (Lee, Lin \& Yu, 2012). Ohlson (2001) called this variable "mysterious" and stated that analysts' forecasts are a reasonable tool to measure expected future earnings (Cupertino \& Lustosa, 2006).

Although this line of approach potentially fulfills the missing link in Ohlson's model, the focus inevitably turned on whether the "other information" was correctly specified and how well they fit the model. However, as the "other information" cannot be fully specified, the essence and spirit of Ohlson's dynamic process for relating market value to book value and abnormal earnings are largely ignored or forgotten (Lee, Lin \& Yu, 2012). In addition, in the specific case of Brazilian companies, the three studies conducted in Brazil (Lima (2008), Ferreira (2010) and Schuch (2013)) that used analysts' prediction as proxy for the variable "other information" provided statistically insignificant results.

Thus, this study considered a different methodology from the other studies published in Brazil, using only the two accounting variables contained in the Ohlson model (1995) to evaluate Brazilian companies listed in B3 (formerly BM \& FBOVESPA). For this, we used the cointegration methods for panel data and estimation of the long-term coefficients for the whole sample, as well as cointegration for time series and estimation of the long-run coefficients for the most liquid companies in B3. The methodologies are based on some papers such as those of Qi, Wu and Xiang (2000), Lee, Chen and Tsa (2014), Vázquez, Valdés and Porras (2011), Valdés and Vázquez (2010), Galdi and Lopes (2007) and Moura and Coelho (2013).

Thus, this study investigated the following research problem: to what extent can the accounting variables used in the Ohlson model predict future movements of stock prices in the Brazilian market without the need to estimate the "other information" vector contained in the model, considering the long-term cointegration approach?

The objective of this work is to verify if there is a long-term equilibrium relation between the market value and the variables accounting book value and abnormal earnings, contained in the Ohlson model (1995). For this, the cointegration methodologies were used, in addition to estimating the relationships of the variables in the long term. This study is divided into four parts, besides this introduction: (i) theoretical reference; (ii) methodology; (iii) results and (iv) conclusions.

\section{Theoretical Framework}

\subsection{The Underlying Theory: Value Relevance of Accounting Information}

The accounting information is considered value-relevant when they have an expected association with the market value of the equity. Thus, if a significant association is found, it is assumed that the accounting information of interest to the research is relevant to investors and reliable enough to be reflected in stock prices (Song, Thomas \& Yi, 2010). Amir, Harris and Venuti (1993) were the first to use the term "value relevance" to describe this association (Suadiye, 2012).

The value relevance can be measured through the statistical relationships between the information presented by the financial statements and the market values or stock returns. The value relevance of the accounting information has been studied in many perspectives. The paper of Miller and Modigliani (1966) was one of the first studies that investigated relationships between accounting numbers and other financial parameters. The authors investigated the factors that affect investment by developing effective methods to infer the cost of capital relevant to optimal investment decisions from securities market value in the electricity industry (Miller \& Modigliani, 1966; Kargin, 2013).

Subsequently, Ball and Brown's (1968) seminal paper studied the relationship between stock returns and earnings. According to Ohlson (1991), the role of Ball and Brown (1968) work had an enormous influence on the research of modern empirical accounting, since its analysis led to an informative perspective on accounting data. Since Ball and Brown (1968), several studies have investigated the association between stock prices or returns and the information disclosed in the financial statements, such as Ohlson's study (1995) (Suadiye, 2012).

Ohlson's model (1995) has been used in many studies to explore the relationship between equity market value and two main financial reporting variables, ie the book value of equity (included in the balance sheet) and earnings (represented in the income statement) (Kargin, 2013). Since 1995, the Ohlson model has been extensively tested on stock market data from many countries under differentapproaches. Most of the literature on the value relevance of the accounting information has comprehensively documented the statistical association between earnings, book values and stock prices 
(or returns). For example, Collins, Maydew, and Weiss (1997), using Ohlson's (1995) valuation framework, investigated the value relevance of earnings, book value, and their combination using a sample of US companies. They found that earnings and book value are value-relevant and together account for $54 \%$ of the cross-sectional variation of stock price (Suadiye, 2012).

Thus, the next topic will explore the theoretical aspect and development of the Ohlson Model (1995).

\subsection{Ohlson Model (1995)}

Ohlson (1995) structured a valuation model, based on the clean surplus relation (CSR), where accounting variables have a prominent role (Cupertino \& Lustosa, 2006). The author then proposed the Residual Income Valuation Model (RIV), in which earnings are the basis for the calculation of the company's value (Lopes, Sant'anna \& Costa, 2007).

The Ohlson Model (1995) is derived from the dividend flow method. In it, the company's value is obtainedas the sum of the book value of the company's equity and the present value of expected (abnormal) residual earnings (Galdi, Teixeira \& Lopes, 2008). The model satisfies many appealing properties, and it provides a useful benchmark when one conceptualizes how market value relates to accounting data and other information (Ohlson, 1995).

The paper develops and analyzes a model in which the firm's market value is related to contemporaneous and future earnings, book values, and dividends. Two accounting theories provided the fundamentals for the model: that the clean surplus relation holds and that dividends reduce current book value but do not affect current earnings (Ohlson, 1995).

Accounting assigns an important integrative function to the statement of changes in owners' equity. Its format requires the change in book value to equal earnings minus dividends (net of capital contributions). This relationship is called clean surplus relation because, all changes in assets/liabilities unrelated to dividends must pass through the income statement (Ohlson, 1995).

Thus, Ohlson's (1995) study assumes that the value of the company is equal to the present value of the expected dividends. One can next assume the clean surplus relation to replace dividends with earnings/book values in the present value formula. Specifically, the core of the valuation function expresses value as a weighted average of (i) capitalized current earnings (adjusted for dividends) and (ii) current book value (Ohlson, 1995).

Regarding the second theory, that dividends reduce the book value of equity but do not affect current earnings, it was observed that this characteristic is relevant when one identifies the economy inherent to the assumption of abnormal earnings dynamics combined with the clean surplus relation. Initial observations are (Ohlson, 1995):

(i) An increase in dividends at any given date reduces the subsequent period's expected earnings. Because risk neutrality obtains, the marginal effect of a dollar of dividends on next period's foregone expected earnings equals the risk-free rate;

(ii) More generally, an increase in dividends reduces the subsequent two periods' aggregate earnings. The two-period compounded interest rate determines this effect.

These two consequences of distributing wealth to the owners extend the more basic requirement that dividends reduce book value but leave current earnings unchanged. Dividends have effects on future accounting data as well as on current accounting data. All of these constructs effectively relate to the idea that earnings in the future partially depend on today's book value. This dependence becomes explicit if one transforms the abnormal earnings dynamics to express next-period expected earnings as a function of current book value, as well as current earnings and dividends (Ohlson, 1995).

Three assumptions formulate the valuation model. First, as is standard in neoclassical models of security valuation, the present value of expected dividends (PVED) determines the market value. To keep matters simple, risk neutrality applies so that the discount factor equals the risk-free rate. Second, regular owners' equity accounting applies: accounting data and dividends satisfy the clean surplus relation, and dividends reduce book value without affecting current earnings (Ohlson, 1995).

Finally, in the third assumption, a linear model frames the stochastic time-series behavior of abnormal earnings. This variable is defined as current earnings minus a charge for the use of capital. Since PVED and the clean surplus relation imply that the market value equals the book value plus the present value of future expected abnormal earnings, the valuation analysis can focus on the prediction of abnormal earnings rather than dividends. The variable "other information" satisfies a (regular) autoregressive process. The two dynamic equations combine with the clean surplus relation to ensure that all value-relevant events will be absorbed by current or subsequent periods' earnings and book values (Ohlson, 1995).

The three assumptions lead to a linear, closed-form, valuation solution explaining goodwill, that is, value equals book value plus a linear function of current abnormal earnings and the scalar variable representing other information. A 
simple restriction eliminates the scalar variable in both the valuation function and the abnormal earnings dynamics; the case shows that current abnormal earnings determine goodwill if, and only if, abnormal earnings satisfy an autoregressive process (Ohlson, 1995).

Considering an economy with risk neutrality and homogeneous beliefs, the development of the model begins with its first premise, that the market value of the firm is equal to the present value of future expected dividends. Given that interest rates satisfy a non-stochastic and flat term structure, the first assumption reduces to (Ohlson, 1995):

$$
P_{t}=\sum_{\tau=1}^{\infty} R_{f}^{-\tau} E_{t}\left[d_{t+\tau}\right]
$$

where:

$P_{t}$ : the market value, or price, of the firm's equity at date $\mathrm{t}$.

$d_{t}$ : net dividends paid at date $t$.

$R_{f}$ : the risk-free rate plus one.

$E_{t}[$.$] : the expected value operator conditioned on the date \mathrm{t}$ information.

With respect to the second premise, it is observed that the change in the book value between two dates is equal to earnings minus dividends, that is, the model imposes the clean surplus relation, which can be formulated as follows (Ohlson, 1995):

where:

$$
y_{t-1}=y_{t}+d_{t}-x_{t}
$$

$x_{t}$ : earnings for the period $(t-1, t)$;

$y_{t}$ : (net) book value at date $\mathrm{t}$.

One can apply the clean surplus relation to express $P_{t}$ in terms of future (expected) earnings and book values in lieu of the sequence of (expected) dividends in the Equation 1. Define (Ohlson, 1995):

$$
x_{t}^{a} \equiv x_{t}-\left(R_{f}-1\right) y_{t-1}
$$

where:

$x_{t}^{a}$ : abnormal earnings.

Combined with the clean surplus restriction, the definition implies (Ohlson, 1995):

$$
\mathrm{d}_{\mathrm{t}}=\mathrm{x}_{\mathrm{t}}^{\mathrm{a}}-\mathrm{y}_{\mathrm{t}}+\mathrm{R}_{\mathrm{f}} \mathrm{y}_{\mathrm{t}-1}
$$

Using this expression to replace $d_{t+1}, d_{t+2}, \ldots$ in the formula 1 yields the equation (Ohlson, 1995):

$$
\mathrm{P}_{\mathrm{t}}=\mathrm{y}_{\mathrm{t}}+\sum_{\tau=1}^{\infty} \mathrm{R}_{\mathrm{f}}^{-\tau} \mathrm{E}_{\mathrm{t}}\left[\tilde{\mathrm{x}}_{\mathrm{t}+\tau}^{\mathrm{a}}\right]
$$

Thus, the formula has a straightforward and intuitively appealing interpretation: a firm's value equals its book value adjusted for the present value of anticipated abnonnal eamings. (Ohlson, 1995).

The third and final assumption concerns the time-series behavior of abnormal earnings. Two variables enter the specification: abnormal eamings, $x_{t}^{a}$, and information other than abnormal earnings, $V_{t}$ (Ohlson, 1995).

Assume $\left\{\tilde{x}_{\tau}^{a}\right\}_{\tau \geq 1}$ satisfies the stochastic process (Ohlson, 1995):

$$
\begin{gathered}
\tilde{\mathrm{x}}_{\tau+1}^{\mathrm{a}}=\omega \mathrm{x}_{\mathrm{t}}^{\mathrm{a}}+\mathrm{V}_{\mathrm{t}}+\varepsilon_{1 \mathrm{t}+1} \\
\widetilde{\mathrm{V}}_{\mathrm{t}+1}=+\mathrm{YV}_{\mathrm{t}}+\varepsilon_{2 \mathrm{t}+1}
\end{gathered}
$$

where the disturbance terms $\varepsilon_{1 \tau}, \varepsilon_{2 \tau}, \tau \geq 1$, are unpredictable, zero-mean, variables; that is: $E_{t}\left[\varepsilon_{k t+\tau}\right]=0, \mathrm{k}=1,2$ and $\tau \geq 1$ (Ohlson, 1995).

This third assumption places no restrictions on the variances and covariances of the disturbance terms. For example, the variances may be heteroscedastic (Ohlson, 1995).

The parameters of the process, $\omega$ and $Y$, are fixed and "known". It is restricted that these parameters are non-negative and less than one. The last condition implies that the unconditional means of $x_{t}^{a}$ and $V_{t}$, are zero (Ohlson, 1995). 
Equation 6 dictates that the coefficient associated with $V_{t}$ equal to one without loss of generality. The issue is simply one of scaling. Further note that $V_{t}$ is irrelevant in the dynamics if $V_{0}=\varepsilon_{2 \tau}=0$, all $\tau \geq 1$. This special case is equivalent to $V_{1}=V_{2}=\ldots=0$ and $\left\{x_{\tau}^{a}\right\}_{\tau}$ satisfies a regular autoregressive process (Ohlson, 1995).

Equation 7 shows that the predictions $E_{t}\left[\tilde{V}_{t+\tau}\right], \tau \geq 1, \mathrm{~T}>1$, depend at most on $V_{t}$, and not on $x_{\tau}^{a}$. They impose the independence because $V_{t}$ should be thought of as summarizing value relevant events that have yet to have an impact on the financial statements. Such information bears upon future (abnormal) earnings independently of current and past (abnormal) earnings. The model also implies that realizations of $V_{t}$ (or $\varepsilon_{2 t}$ ) cannot "bypass" the financial statements. These realizations feed into the $x_{t+1}^{a}, x_{t+2}^{a}, \ldots$ sequence, and each realization of $x_{t}^{a}$, in tum, updates the date $t$ book value via the recursive equation (Ohlson, 1995):

$$
\mathrm{y}_{\mathrm{t}}=\mathrm{x}_{\mathrm{t}}^{\mathrm{a}}+\mathrm{R}_{\mathrm{f}} \mathrm{y}_{\mathrm{t}-1}-\mathrm{d}_{\mathrm{t}}
$$

Based on three assumptions, to derive the valuation function one uses equation 5 and evaluates $\sum_{\tau=1}^{\infty} R_{f}^{-\tau} E_{t}\left[\tilde{x}_{t+\tau}^{a}\right]$ given the dynamics of the third assumption. The linearity in the specification leads, of course, to a linear solution: (Ohlson, 1995):

where:

$$
P_{t}=y_{t}+\alpha_{1} x_{t}^{a}+\alpha_{2} V_{t}
$$

$$
\begin{gathered}
\alpha_{1}=\omega /\left(R_{\mathrm{f}}-\omega\right) \geq 0 \\
\alpha_{2}=\mathrm{R}_{\mathrm{f}} /\left(\mathrm{R}_{\mathrm{f}}-\omega\right)\left(\mathrm{R}_{\mathrm{f}}-\gamma\right) \geq 0
\end{gathered}
$$

Equation 9 implies that the market value equals the book value adjusted for (i) the current profitability as measured by abnormal earnings and (ii) other information that modifies the prediction of future profitability. One eliminates (ii) by restricting $x_{t}^{a}$ to satisfy an autoregressive process. This special version of the third assumption postulates that $V_{t} \equiv 0$, and thus abnormal earnings, alone, determine goodwill if and only if current abnormal earnings suffice in the prediction of future abnormal earnings (Ohlson, 1995).

\subsection{Empirical Evidence}

Qi, Wu and Xiang (2000) investigated the the time-series properties of the Ohlson Model (1995). Based on a sample of 95 companies and with data from 1958 to 1994, they showed that the null hypothesis that market value and book value are not stationary could not be rejected for most firms in the sample. In addition, they found that book value and abnormal earning do not cointegrate with the market value for 80 percent of the firms. Thus, they concluded that the direct tests of the Ohlson model (1995) through OLS regressions using time-series data for these firms are questionable because they are unlikely to be specified.

Valdés and Vázquez (2010) used cointegration methods to investigate the relationship between Ohlson model variables (stock price, earnings per share and book value) with panel data for Mexican companies from 1997 to 2008 . The tests of cointegration were applied at individual and group level (by all companies and by sectors). The empirical results, based on the Johansen test, indicated that there are some individual cointegration relationships. The panel cointegration test showed that the variables in the Ohlson model are not cointegrated for the Construction sector, although they are for the Commercial and Food and Beverage sectors.

Vázquez, Valdés and Porras (2011) investigated the determinants of stock prices in six emerging Latin American markets (Argentina, Brazil, Chile, Colombia, Mexico and Peru). To do so, they tested the traditional Ohlson model and an international version of it, which included the Dow Jones index as an additional explanatory variable. Using time series and panel data cointegration methodologies to evaluate the long-term relationships between the variables postulated by both models and using quarterly data for the period 2000 to 2010 , they found that panel data techniques may be better than time series for the evaluations. They supported the use of Ohlson models, and especially international models. The results were valid for the general sample and for commercial and construction companies.

Lee, Chen, and Tsa (2014) used a panel cointegration method to test the Ohlson model (1995). The sample consisted of listed companies in the US during the period from 1986 to 2004. The objective was to know if the fundamental value of the companies are cointegrated with market value. The results supported the hypothesis of cointegration that there is a long-term equilibrium relationship between the fundamental value of a company and its market value. Subsequently, the study evaluated the predictive power of the Ohlson model for the future evaluation of market value. The results showed that the Ohlson model can predict future stock price movements much more accurately over any given horizon. 


\section{Methodology}

The methodology applied in this study is based on the works of Qi, Wu and Xiang (2000), Lee, Chen and Tsa (2014), Vázquez, Valdés and Porras (2011), Valdés and Vázquez (2010), Galdi and Lopes (2007) and Moura and Coelho (2013), who used panel data and time series cointegration to test the Ohlson Model in several markets.

Theoretically, cointegration means that although the dependent variable and some of the regressors are not stationary, there is still a long-run equilibrium relationship linking the individual regressors together to the dependent variable. In the Ohlson model (1995), this means that even if market value, book value and perhaps abnormal earning are not individually stationary, the market value is still related to book value and abnormal earning through a stable process. Empirically, cointegration means that the error term will be stationary even if the dependent variable and some of the independent variables are therefore not satisfying one of the fundamental assumptions of the OLS regression. Engle and Granger (1987) further prove that OLS estimates are consistent if cointegration occurs, but would be inconsistent in the absence of cointegration (Qi, Wu \& Xiang, 2000). In other words, it uses the cointegration methodology to avoid the estimation of long-term spurious relations.

The existence of non-estationarity in economic and accounting series implies that tests of cointegration between economic variables and accounting are necessary for a more realistic modeling of the behavior of the action. There is considerable incentive to study the long-run equilibrium relationship between stock prices and the fundamental value of corporations in Ohlson's accounting-based stock valuation model (Lee, Chen \& Tsa, 2014).

According to Vázquez, Valdés and Porras (2011), future studies on the Ohlson model should verify cointegration for time series and panel data. In addition, for emerging markets, cointegration studies for panel data may be required to combine the properties of time series and cross-sectional data and take advantage of the available data (Vázquez, Valdés \& Porras, 2011).

The sample was composed of all companies listed in B3. However, those who had negative equity in the study period were excluded from the sample, since, according to Cupertino (2003) and Schuch (2013), they cannot be interpreted economically, since any cash flow model presupposes the continuity of companies in the economy, a premise that would probably not be fulfilled if the equity value were negative. Companies from the financial sector were droppedas well as companies with missing data in any year during the sample period.Thus, the final sample comprised a total of 82 companies that had shares listed in B3 between 2005 and 2016. The choice of period was due to the greater availability of data, with the intention of considering more companies in the sample, since the smaller the period, the greater the number of companies with shares traded in the considered time.

These companies were grouped based on their type of economic activity. For this, the sectoral classification of B3 was used. According to Vázquez, Valdés and Porras (2011), the heterogeneity of these economic activities suggests that company performance and specific stock prices may depend on conditions prevailing in local and global markets. In addition, a group of the most liquid companies of B3 was selected, totaling 48 companies in the sample period, to employ atime-series analysis.

The independent variables used were book value and abnormal earning, both calculated by equations 2 and 3 of Ohlson (1995). The dependent variable is the market value of the companies. All variables in the study were deflated by the number of common shares outstanding at the end of the year, following the procedure adopted by Dawar (2014). Christen and Grottkle (2015) argue that an alternative to exclude effects of scale of effects of heteroscedasticity is to divide all variables by the number of shares in circulation. Lee, Chen and Tsa (2014) and Vázquez, Valdés and Porras (2011) performed this procedure in their papers, which evaluated the existence of cointegration of the Ohlson Model variables.

Data were obtained through the databases of Bloomberg and Economática. Subsequently, they were treated and tabulated in Microsoft Excel spreadsheets. For the realization of econometric calculations and tests, the software Eviews and Stata were used.

For the econometric procedures, the work follows some sequential steps:

(i) Panel data cointegration methodology for the whole sample and for the groups of economic sectors and most liquid companies, aiming at an initial analysis of cointegration that avoids the estimation of spurious relations of long term between the variables;

(ii) Long-term parameter estimates with the dynamic ordinary least squares (DOLS) regression models for panel data for the groups considered cointegrated in methodology $i$;

(iii) Time series cointegration methodology, with the objective of verifying the existence of cointegration between the variables for each company, being chosen only the group of the most liquid companies of B3, if their variables are cointegrated; 
(iv) Long-term parameter estimates with the DOLS regression models for time series for the most liquid companies of B3, if their variables are cointegrated in the methodology iii.

Each methodological procedure will be detailed in the next topics.

\subsection{Panel Data Cointegration}

Cointegration refers to circumstances in which non-stationary variables are interconnected through a long-run equilibrium relationship. Although Ohlson's model did not consider the non-stationarity of market value, book value, and abnormal earning, the market value can still be related to book value and abnormal earning through cointegration. If equity valuation models are valid representations of long-term stock price behavior, stock prices will deviate from their capital fundamentals only in the short term (Lee, Chen \& Tsa, 2014; Teixeira, 2017).

The panel data cointegration methodology had four main steps: (i) cross section dependency tests; (ii) unit root tests; (iii) cointegration tests and (iv) parameter estimation.

\subsubsection{Cross Section Dependency Tests}

According to Cardoso and Bittencourt (2013), cross section dependence can generate spurious regressions for most estimators and this is a problem that is rarely addressed in empirical studies that use panel data.

The present paper used the Pesaran (2004) test with the null hypothesis that there is no dependence between cross sections. In addition to the reason cited in the previous paragraph, this test was used to decide which type of unit root test will be used, since a test group called the first generation considers that the series do not have cross section dependence, while the second generation group allows such problem.

\subsubsection{Unit Root Tests}

The unit root tests in panel data were developed with the aim of giving greater robustness to the traditional stationarity tests of time series, since they combine information of the dimension of the time series with the dimension cross section (Banerjee, 1999). They aim to check whether the variables in the model are stationary or not, that is, if the individual series contain unit roots.

The first step in making the cointegrated panel is to check if the series are non-stationary in level. If the series is non-stationary, it can be made stationary through differentiations of the original series. Thus, it is said that a series is integrated of first order I (1) when it is applied once the difference in the original series to obtain stationarity.

We estimated the order of integration of the variables with four different unit root tests: Im, Pesaran and Shin (IPS) (2003), Maddala and Wu (Fischer-ADF) (1999), Levin, Lin and Chu ) (2002) and Hadri LM (2000). This last one was used because it allows the cross section dependence, since the first three do not consider this problem. Thus, it took four tests because they assume different assumptions about the nature of the data.

\subsubsection{Cointegration Testing}

To perform the panel cointegration tests, the tests proposed by Pedroni (1999) and Kao (1999), which have as null hypothesis the non-cointegration for the data of the sample, are applied.

The Pedroni (1999) tests allow multiple regressors, that the cointegration vector varies between the different sections of the panel, and also the heterogeneity in the error through units of cross sections. The Kao (1999) tests are DF and ADF tests based on residuals for the cointegration in the panel data, and impose homogeneous vectors of cointegration. However, it does not allow multiple exogenous variables on the cointegration vector, nor does it identify cases where there is more than one cointegration vector (Rivera, Martin, Marçal \& Basso, 2012).

The Pedroni (1999) methodology is based on seven tests, in which four are based on the within dimension (panel cointegration tests) and the other three are based on the dimension between (group mean panel cointegration tests). The group mean panel cointegration statistic is more general, allowing the heterogeneity of the coefficients under the alternative hypothesis (Rocha \& Barbi, 2009).

The Pedroni (1999) and kao (1999) tests are based on the Engle-Granger (1987) methodology, which examines the residuals of a regression performed using integrated variables of order (1); if there is cointegration, then the residuals must be I (0) (Scarpelli, 2010).

\subsubsection{Long-Term Estimates For Panel Data}

Once observed that the cointegration relation really exists, the long term parameters can be estimated efficiently using techniques similar to those of time series models. In this study, the DOLS (Dynamic Ordinary Least Squares) estimators will be used.

By means of these estimators will be observed if the variables book value and abnormal earning are statistically significant to explain the variable market value for the groups of companies analyzed. 
Kao (1999) compared the efficiency of the OLS (Ordinary Least Squares), FMOLS (Fully Modified Ordinary Least Squares) and DOLS estimators and concluded that the OLS estimator has a bias that is not negligible for small samples and presence of heteroscedasticity. Alternative methods such as the FMOLS and DOLS estimators present better performance by performing a correction for endogeneity and serial correlation of the regressors. The FMOLS promotes a semi-parametric correction to the OLS estimator, whereas the DOLS a parametric correction (SCARPELLI, 2010). Kao and Chiang (2000) found in their study that the DOLS estimator exceeds the OLS and FMOLS estimators, which is why it will be used in this paper.

Subsequently, time series cointegration methods were used individually for the most liquid companies in B3.

\subsection{Time Series Cointegration}

This methodology had three main steps: (i) unit root tests; (ii) cointegration test and (iii) parameter estimation.

\subsubsection{Unit Root Tests}

A stochastic process is considered to be stationary if its mean and variance are constant over time and the value of covariance between the two time periods depends only on the distance, interval or lag between the two periods and not the actual time at which the covariance is computed. It is important that the series studied have this characteristic, since if a time series is non-stationary, it is only possible to study its behavior only for the period of time under consideration. As a consequence, it is not possible to generalize it for other periods, being of impractical value for the purpose of making forecasts (Gujarati \& Porter, 2011). In addition, regressions between non-stationary variables may result in the spurious regression problem (Galdi \& Lopes, 2007).

When a series is non-stationary, it is said that it has a unit root. The importance of knowing if a series has unit root lies in the fact that, if affirmative, the external shocks cause permanent effect in the series. In a stationary series, there is a return to the average after some time (Dawid, 2004).

Several econometric tests were developed with the objective of identifying whether or not a series has a unit root. Among them are the Augmented Dickey-Fuller (ADF), Phillips-Perron (PP) and Kwiatkowski-Phillips-Schmidt-Shin (KPSS) tests. In the ADF and PP tests, the null hypothesis is that there is a unit root in the series, while in the KPSS test the null hypothesis is that there is no unit root in the series, ie, it is stationary. The three tests will be used in this work.

Methodologically, it is necessary to verify if each variable of the time series associated to each company is stationary in first difference, that is, if they are I (1). This is the first necessary condition to analyze the cointegration between the studied variables.

\subsubsection{Johansen Cointegration Test}

The regression of a non-stationary time series into another non-stationary time series can produce a spurious regression. When the series are cointegrated it means that, even if they are individually non-stationary, a linear combination of two or more of them may be stationary (Galdi \& Lopes, 2007). Economically speaking, the two variables will be cointegrated if they have a long-term relationship, or equilibrium, between them (Gujarati \& Porter, 2011).

One of the tests used for cointegration analysis in time series is that of Johansen (1991) (Galdi \& Lopes, 2007). The first question to be analyzed in the method is whether there is cointegration. If so, the number of cointegration vectors in the system is determined (Sonza \& Kloeckner, 2009). For this, its procedure uses two statistics: (i) trace statistic, with null hypothesis that there are at most $r$ cointegration vectors and (ii) statistic of maximum eigenvalue, with null hypothesis that there are exactly $\mathrm{r}$ cointegration vectors (Galdi \& Lopes, 2007).

When the variables are cointegrated, one can perform the long-term estimation with the DOLS models.

\subsubsection{Long-Term Estimates for Time Series}

Once observed that the cointegration relation really exists, the long term parameters of the companies can be estimated efficiently using the DOLS estimators. By means of them it will be observed if the variables book value and abnormal earning are statistically significant to explain the variable market value of the most liquid companies of B3.

\section{Results}

In this section the results of the study are analyzed and discussed. The analysis of the descriptive statistics of the general data of the economic sectors was carried out a priori based on the classification of B3 and the group of the most liquid companies of B3. Subsequently, the methodological procedures indicated in items i to iv of section 3 were performed.

\subsection{Descriptive Statistics}

Initially, the number of total and group companies that were part of the study sample is presented. The data can be seen in Table 1. 
A total of 82 companies are divided into eight economic sectors, according to B3 classification. Among them, the largest number of companies is in the Public Utility sector with 24 companies, followed by the Cyclical Consumption sector with 16 companies and by the Basic Materials and Industrial Goods sectors, with 14 companies each. On the other hand, those with the lowest quantitative levels are the Health and Petroleum, Gas and Biofuel sectors, with only 3 companies in the sample. In the latter cases, by the small number of companies, the analyzes may have been compromised. However, we opted for the separation because they are companies with large market values in relation to the others.

Table 1. Number of companies by sector

Source: Self elaboration.

\begin{tabular}{clc}
\hline $\mathbf{N}^{\circ}$ & \multicolumn{1}{c}{ Sectors } & $\mathbf{N}^{\circ}$ of Companies \\
\hline $\mathbf{1}$ & General data & $\mathbf{8 2}$ \\
\hline 2 & Public utility & 24 \\
\hline 3 & Cyclic Consumption & 16 \\
\hline 4 & Basic Materials & 14 \\
\hline 5 & Industrial Goods & 14 \\
\hline 6 & Non Cyclic Consumption & 4 \\
\hline 7 & Telecommunications & 4 \\
\hline 8 & Health & 3 \\
\hline 9 & Oil, Gas and Biofuels & 3 \\
\hline
\end{tabular}

The study also selected the group of the most liquid companies of B3, considering the quantities of negotiations during the study period. The group was initially composed of 48 companies.

Table 2 presents the descriptive statistics of the dependent variable Market Value of the companies for each group analyzed.

It is observed that in all groups the median is less than the average, which can be concluded that some high figures of market value of the companies increase the average and the standard deviation of the whole sector. In these cases, the median becomes a measure of better accuracy.

Thus, considering the median, the sector with the highest market value was Non-Cyclic Consumption, followed by the Oil, Gas and Biofuels and Telecommunications sectors. On the other hand, the sector with the lowest median was Industrial Goods.

Table 2. Descriptive statistics of the variable Market Value (in thousands)

\begin{tabular}{l|r|r|r}
\hline \multicolumn{1}{c|}{ Sectors } & \multicolumn{1}{c|}{ Average } & Medium & Standard deviation \\
\hline General data & $13,629,160.22$ & $3,732,160.50$ & $40,688,873.70$ \\
\hline Public utility & $6,253,592.97$ & $4,277,242.00$ & $6,797,803.26$ \\
\hline Cyclic Consumption & $3,125,059.50$ & $2,075,383.00$ & $3,737,929.00$ \\
\hline Basic Materials & $20,328,150.46$ & $6,847,079.00$ & $46,692,816.50$ \\
\hline Industrial Goods & $4,055,309.21$ & $606,630.00$ & $7,246,543.87$ \\
\hline Non Cyclic Consumption & $55,756,215.85$ & $20,142,547.50$ & $80,330,536.80$ \\
\hline Telecommunications & $16,748,888.81$ & $13,636,235.00$ & $17,388,928.20$ \\
\hline Health & $3,178,105.75$ & $2,225,059.50$ & $3,933,994.65$ \\
\hline Oil, Gas and Biofuels & $92,193,594.33$ & $17,034,771.00$ & $125,244,824.81$ \\
\hline Liquid Companies & $21,252,068.59$ & $6,342,036.00$ & $53,230,051.83$ \\
\hline
\end{tabular}

Source: Self elaboration.

Table 3 presents the descriptive statistics of the general sample for the three variables of the Ohlson Model (1995). The results show that company data vary widely around the mean, given the discrepancy between the maximum and minimum values and the high value of the standard deviation. Hence the importance of dividing the companies by sectors of action, besides deflating the variables by the number of actions, in order to exclude the effect of scale, procedures that will be carried out in this work.

Table 3. Descriptive statistics of variables (in thousands)

\begin{tabular}{|c|c|c|c|}
\hline Descriptive statistics & Market Value & Book Value & Abnormal Earnings \\
\hline Average & $13,629,160.22$ & $8,816.35$ & $-\quad 213.22$ \\
\hline Medium & $3,732,160.50$ & $1,740.65$ & 5.36 \\
\hline Minimum & $5,375.00$ & $1,463.97$ & $78,803.16$ \\
\hline Maximum & $429,922,948.00$ & $348,569.39$ & $25,122.46$ \\
\hline Standard deviation & $40,688,873.70$ & $30,230.77$ & $4,864.92$ \\
\hline
\end{tabular}


Source: Self elaboration.

In the next section we begin the econometric analysis of this study, firstly with the methodology of panel data cointegration.

\subsection{Panel Data Cointegration}

The methodology of panel data cointegration involves three steps: cross section dependency tests, unit root tests, and cointegration tests per se.

\subsubsection{Cross Section Dependency Tests}

The results of Pesaran (2004) cross-section dependency test are presented in Table 4, for both the general sample and the groups. The null hypothesis of the test is that there is no cross section dependence. Thus, considering a level of significance of 5\%, used in this study, a variable that has statistic below this value presents cross section dependence.

Table 4. Pesaran (2004) Test

\begin{tabular}{|c|c|c|c|}
\hline Sample & Variable & Stat. & Prob. \\
\hline & M.V. & $33.62566 *$ & 0.0000 \\
\hline \multirow[t]{3}{*}{ General } & B.V. & $54.79528 *$ & 0.0000 \\
\hline & A.E. & $30.52450 *$ & 0.0000 \\
\hline & M.V. & $16.01737 *$ & 0.0000 \\
\hline \multirow[t]{3}{*}{ Public utility } & B.V. & $18.10752 *$ & 0.0000 \\
\hline & A.E. & $8.301339 *$ & 0.0000 \\
\hline & M.V. & $7.444955 *$ & 0.0000 \\
\hline \multirow[t]{3}{*}{ Cyclic Consumption } & B.V. & $13.94130 *$ & 0.0000 \\
\hline & A.E. & $8.226585 *$ & 0.0000 \\
\hline & M.V. & $9.645043 *$ & 0.0000 \\
\hline \multirow{3}{*}{ Basic Materials } & B.V. & 1.694359 & 0.0902 \\
\hline & A.E. & $6.185395 *$ & 0.0000 \\
\hline & M.V. & $5.282501 *$ & 0.0000 \\
\hline \multirow[t]{3}{*}{ Industrial Goods } & B.V. & $11.63137 *$ & 0.0000 \\
\hline & A.E. & $9.851726 *$ & 0.0000 \\
\hline & M.V. & $5.128413 *$ & 0.0000 \\
\hline \multirow[t]{3}{*}{ Non Cyclic Cons. } & B.V. & $4.578447 *$ & 0.0000 \\
\hline & A.E. & $2.689799 *$ & 0.0071 \\
\hline & M.V. & $2.091372 *$ & 0.0365 \\
\hline \multirow[t]{3}{*}{ Telecommunications } & B.V. & -0.028335 & 0.9774 \\
\hline & A.E. & 0.260932 & 0.7941 \\
\hline & M.V. & $3.284981 *$ & 0.0010 \\
\hline \multirow[t]{3}{*}{ Health } & B.V. & $5.738474 *$ & 0.0000 \\
\hline & A.E. & -0.070809 & 0.9435 \\
\hline & M.V. & -0.758129 & 0.4484 \\
\hline \multirow[t]{3}{*}{ Oil, Gas and Biofuels } & B.V. & 0.977028 & 0.3286 \\
\hline & A.E. & 0.028288 & 0.9774 \\
\hline & M.V. & $17.48128 *$ & 0.0000 \\
\hline \multirow[t]{2}{*}{ Liquid Companies } & B.V. & $32.79154 *$ & 0.0000 \\
\hline & A.E. & $18.90609 *$ & 0.0000 \\
\hline
\end{tabular}

Source: Self elaboration.

Analyzing the table, it can be noticed that a pattern was not found among the variables, some of which have cross section dependence and others do not. However, most of the analyzed groups presented cross-section dependence in the three variables. These are the cases of the General and Net Companies groups and of the sectors Public Utilities, Cyclical Consumption, Industrial Goods and Non-Cyclic Consumption. The Oil, Gas and Biofuel sector presented cross-section independence in the three variables. The Basic Materials sector presented cross-section independence only in the book value variable and the Health sector only in the abnormal earning variable. On the other hand, the Telecommunications sector showed dependence only on the variable market value.

Considering these results, it was possible to choose the most appropriate panel data unit root tests, since one of the tests considers the cross section dependence and the others do not. The results of these tests are discussed in the next topic. 


\subsubsection{Unit Root Tests}

While in the tests of IPS (2003), Fisher ADF (1999) and LLC (2002) the null hypothesis is that there is unit root, in the test Hadri LM (2000) the null hypothesis indicates no unit root in any of the series in the panel. His alternative hypothesis is that there is at least one unit root in the panel. The first group of tests was used for the variables that did not present cross section dependence, whereas the test of Hadri LM (2000) was used for the companies that presented dependency, since the test allows the inclusion of this problem.

The results for the IPS (2003), Fisher ADF (1999) and LLC (2002) tests are in Table 5 of Appendix A, while the Hadri LM (2000) test outputs are in Table 6 of Appendix B. In relation to the first three, in cases where the variable presented a conflict of results, most of them were considered for decision making. For example, if the IPS and Fisher methods accused stationarity and the LLC did not stationarity, the variable was considered stationary. The variables were observed at the level and first difference.

By the analysis of Tables 5 and 6, it is observed that all variables of all groups analyzed are non-stationary in level, but stationary in first difference, that is, are I (1). According to Gujarati and Porter (2011), the panel cointegration tests require that the analyzed variables be of the same order. They argue that when the variables are I (1), they contain a stochastic tendency, necessary so that their regression is not necessarily spurious. Thus, if the variables are individually I (1), but their linear combination is I (0), this combination is supposed to eliminate the stochastic tendency of the series. In this case, we affirm that the variables are cointegrated, that is, they have a long-term relationship, or equilibrium, between them (Gujarati \& Porter, 2011).

In this way, the next topic presents the results of the cointegration tests for all the groups, since their variables confirmed to be stationary in the first difference and are, therefore, eligible for the cointegration evaluations.

\subsubsection{Pedroni and Kao Cointegration Tests}

The results of the Pedroni (1999) cointegration tests are in Table 7 of Appendix C, whereas those of the Kao (1999) Test are in Table 8 of Appendix D. Both have as null hypothesis the non-cointegration for the data of the sample. Thus, a probability of value below $5 \%$ means that there is cointegration in the panel.

Regarding the Pedroni (1999) methodology, since it has seven tests, it is necessary that most of them (at least four) are significant. Table 7 shows that, of the ten groups analyzed, the Basic Materials, Telecommunications and Health sectors did not reject the null hypothesis of non-cointegration, considering a significance of $5 \%$. The other groups were considered cointegrated.

In relation to the Kao (1999) methodology, Table 8 shows that all the results confirmed the cointegration, except for the sectors of Non-Cyclical Consumption and Telecommunications. Considering the results of the two tests, it was preferred to exclude the Telecommunications sector from the analysis, because it was considered as non-cointegrated in both tests.

Thus, the general conclusion of the tests is that there is a stable long-term relationship between the variables market value, book value and abnormal earning for the General sample, for the most liquid companies of B3 and for the Utilities, Consumption Cyclic, Basic Materials, Industrial Goods, Non-Cyclic Consumption, Health and Petroleum, Gas and Biofuels, that is, they really cointegrate. Therefore, it is feasible to use the DOLS estimators.

\subsubsection{Long-Term Estimates for Panel Data}

The results of the DOLS estimators are shown in Table 9 of Appendix E. The value of the long-run coefficient, along with the p-value, is presented for each Ohlson model variable and analyzed group.

Analyzing the results, it can be observed that the variables book value and abnormal earning presented a positive and significant relation to explain the market value in the groups of the General sample and in the sectors Public Utilities and Cyclical Consumption. A positive value coefficient means that if the variable increases, the market value will also increase.

On the other hand, in the Industrial, Non-Cyclic Consumption and Health sectors, none of Ohlson's two variables (1995) was statistically significant at 5\% to explain the companies' market value. In the group of the most liquid companies and in the Basic Materials and Petroleum, Gas and Biofuels sectors, only the variable book value was significant to explain the market value, presenting a positive relation.

Observing the results in a different way, it can be seen that the variable book value was significant to explain the market value in six of the nine analyzed groups (approximately 67\%), while the variable abnormal earning was shown significant difference in only three of the nine groups (approximately $33 \%$ ).

In order to analyze more deeply the hypothesis that the variable abnormal earning would not be significant to explain the market value of most companies by the Ohlson Model (1995), it was chosen to perform time series cointegration 
tests and estimation of parameters for the most liquid companies of B3, since it was the group with the largest number of companies that presented this behavior. The results are presented in the next section.

\subsection{Time Series Cointegration}

The ratio of the companies analyzed is shown in Table 10 of Appendix F. The companies Oi SA, TIM Participações SA and Telefônica Brasil SA were withdrawn from the sample because they belonged to the Telecommunications sector, the only one not considered cointegrated in the panel data analysis. Thus, 45 companies were left in the final sample.

The results of the two tests pertaining to the time series cointegration analysis are presented below: the unit root and Johansen cointegration tests, as well as the long term estimators.

\subsubsection{Unit Root Tests}

Table 11 in Appendix G shows the results of the three unit root tests used in this work. This is the first analysis made in the variables, since it is necessary that the series be stationary in the first difference, that is, I (1), so that we proceed with the cointegration analysis.

As criteria, the companies considered I (1) were selected in at least two of the three tests, to characterize most of them. In addition, we selected the companies that presented themselves as I (1) in all variables by the same test. At the end, 20 of the 45 companies were considered to be stationary in first difference, being later analyzed as to the cointegration of the Ohlson Model (1995) variables.

\subsubsection{Johansen Cointegration Test}

In Table 12 of Appendix $\mathrm{H}$ are the results of the Johansen cointegration test. It is observed that only the company Aes Elpa S.A. did not present its variables as cointegrated. Thus, it can be said that there is a stable long-term relationship between the variables market value, book value and abnormal earning for the other 19 companies. Therefore, it is feasible to use the DOLS estimators for them.

\subsubsection{Long-Term Estimates for Time Series}

Table 13 in Appendix I shows the results of the long-term estimators of the book value and abnormal earning variables, in relation to the dependent variable market value. The value of the long-run coefficient, together with the p-value in parentheses, is presented for each variable.

Analyzing the results, it can be observed that the variable book value presented a positive and significant relation to explain the Market Value of 16 of the 19 companies in the sample (approximately 84\%). A positive value coefficient means that if the variable increases, the market value will also increase. On the other hand, the abnormal earning variable showed only 7 of the 19 companies analyzed (approximately 37\%), all of which were positive.

Thus, it is confirmed the hypothesis raised in this study that the variable abnormal earning is not considered statistically significant to explain the market value of most Brazilian companies listed in B3.

\section{Conclusion}

This study investigated the long-term relationship between the Ohlson Model (1995) variables: market value, book value and abnormal earning. The long-term relationship was tested by (i) panel cointegration analysis for the General sample, for the most liquid companies of B3 and for sectors of economic activities and (ii) for the analysis of time series cointegration for the most liquid companies of B3. For both analyzes, the long-term coefficients were also estimated and the explanatory power of the variables accounting book value and abnormal earning for the estimation of the market value of the companies, considering the DOLS methodology, were also estimated.

The main results of the panel cointegration analysis showed that the variables cointegrate in the General sample, in the most liquid companies group and in all sectors in at least one of the cointegration tests performed. The exception occurred for the Telecommunications sector, which presented no cointegration in both tests. The results of time series cointegration have shown that all firms have cointegrating variables except Aes Elpa S.A. In other words, for these companies, the three variables of the Ohlson Model are able to move together in the long term. In this way, the Ohlson Model (1995) is relevant for the evaluation of these companies in a long-term equilibrium.

On the other hand, for the telecommunications sector and Aes Elpa SA, the variables did not present a long-term equilibrium relationship, ie, they are not cointegrated, leading to the conclusion that the Ohlson Model (1995) does not is relevant for the evaluation of these companies in a long-term equilibrium.

Despite the existence of found cointegration relationships, the two independent variables of the Ohlson Model showed different behaviors to explain the market value in the analyzed groups and companies. It should be noted that there was no explanatory power of the variable abnormal earning for most groups (in the case of panel data), since in only three of the nine groups it was statistically significant to explain the market value. In the case of time series, it was significant in 
only 7 of the 19 companies analyzed. Meanwhile, the book value showed a coefficient with positive and significant relation in the long term with the variable market value for six of the nine groups and for 16 of the 19 companies that presented cointegration.

Thus, the original Ohlson Model (1995) with the use of a risk-free rate and without the "other information" vector would not be efficient in predicting the market value of most companies, since the abnormal earning variable does not showed significant in them.

It is believed that the fact that the abnormal earning did not make a significant difference for most groups and companies occurred because this variable in the Ohlson Model is calculated with the inclusion of a risk-free rate, and the groups/firms theoretically have levels of risk different from each other. Thus, it would be necessary to replace the risk-free rate in the calculation of the abnormal earning at a rate that reflects the level of risk to which each company is exposed, especially considering the emerging market that was the source of that study.

\section{Acknowledgments}

I want to thank Dr. Felipe Paiva - Finance Laboratory of the Federal Center of Technological Education of Minas Gerais (CEFET-MG) - for providing the database of this study.

\section{References}

Amir, E., Harris, T., \& Venuti, E. (1993). A Comparison of the Value-Relevance of US Versus Non-US GAAP Accounting Measures Using Form 20F Reconciliations. Journal of Accounting Research, 31, 230-264. https://doi.org/10.2307/2491172

Ball, R., \& Brown, P. (1968). An empirical evaluation of accounting income numbers. Journal of Accounting Research, 6, 159-177. https://doi.org/10.2307/2490232

Banerjee, A. (1999). Panel Data Unit Root and Cointegration: An Overview. Oxford Bulletin of Economics and Statistics, 61, 607-629. https://doi.org/10.1111/1468-0084.61.s1.12

Barth, M. E., Beaver, W. H., Hand, J. R. M., \& Landsman, W. R. (1999). Accruals, cash flows, and equity values. Review of Accounting Studies, 4(3), 205-229. https://doi.org/10.1023/A:1009630100586

Cardoso, L. C. B., \& Bittencourt, M. V. L. (2013). Mensuração das elasticidades-preço da demanda, cruzada e renda no mercado de etanol brasileiro: um estudo usando painéis cointegrados. Revista de Economia e Sociologia Rural, 5l(4), 765-784. https://doi.org/10.1590/S0103-20032013000400008

Christen, D., \& Grottke, M. (2017). Exploiting qualitative (narrative) information from annual reports for the purpose of accounting based firm valuation - a Markov chain approach. Retrieved from: https://papers.ssrn.com/sol3/papers.cfm?abstract_id=2653114.

Collins, D. W., Maydew, E. L., \& Weiss, I. S. (1997). Changes in the Value-Relevance of Earnings and Book Values Over The Past Forty Years. Journal of Accounting \& Economics, 24(1), 39-67. https://doi.org/10.1016/S0165-4101(97)00015-3

Cupertino, C. M. (2003). O modelo de Ohlson de avaliação de empresas: uma análise crítica de sua aplicabilidade e testabilidade empírica (Doctoral dissertation), University of Brasília - UNB.

Cupertino, C. M., \& Lustosa, P. R. B. (2006). Testabilidade do Modelo Ohlson: revisão da literatura acadêmica. Contabilidade Vista e Revista, 17(2), 47-66.

Dawar, V. (2014). Earnings persistence and stock prices: Empirical evidence from an emerging market. Journal of Financial Reporting and Accounting, 12(2), 1-22. https://doi.org/10.1108/JFRA-06-2013-0044

Dawid, P. E. (2004). Estacionariedade em séries temporais com quebras estruturais (Doctoral dissertation). Institute of Mathematics and Statistics from São Paulo University, São Paulo, Brazil.

Dechow, P. M., Hutton, A. P., \& Sloan, R. G. (1999). An empirical assessment of the residual income valuation Model. Journal of Accounting and Economics, 26(1), 1-34. https://doi.org/10.1016/S0165-4101(98)00049-4

Dung, N. V. (2010). Value-Relevance of Financial Statement Information: A Flexible Application of Modern Theories to the Vietnamese Stock Market. DEPOCEN Working Paper Series $N^{\circ}$ 2010/02. Retrieved from: http://veam.org/wp-content/uploads/2016/06/2009_value-relevanceOfFinancialStatementInformation_nguyenvietd ung.pdf.

Engle, R., \& Granger, C. (1987). Co-integration and Error Correction: Representation, Estimation and Testing. Econometrica, 55, 251-76. https://doi.org/10.2307/1913236

Etemadi, H., \& Mougouie, F. R. (2015). Firm's Life Cycle and Ohlson Valuation Model: Evidence From Iran. Asian 
Economic and Financial Review, 5(4), 641-652. https://doi.org/10.18488/journal.aefr/2015.5.4/102.4.641.652

Fernandez, P. (2013). Company Valuation Methods. Social Science Research Network. Retrieved from: https://ssrn.com/abstract=274973.

Ferreira, R. M. (2010). Testabilidade empírica do modelo de Ohlson: uma investigação sobre a influência das previsões dos analistas no mercado brasileiro (Doctoral dissertation). Federal University of Minas Gerais, Minas Gerais, Brazil.

Galdi, F. C., \& Lopes, A. B. (2007). Relação de longo prazo e causalidade entre o lucro contábil e o preço das ações: evidências do mercado latino-americano. Revista de Administração, 43(2), 186-201. http://dx.doi.org/10.1590/S0080-21072008000200006

Galdi, F. C., Teixeira, A. J. C., Lopes, A. B. (2008). Análise empírica de modelos de valuation no ambiente brasileiro: fluxo de caixa descontado versus Modelo de Ohlson (RIV). Revista de Contabilidade e Finanças da USP, 19(47), 31-43. https://doi.org/10.1590/S1519-70772008000200004

Gujarati, D. N., \& Porter, D. C. (2011). Econometria Básica (5nd ed). Porto Alegre, Brazil: Bookman.

Hadri, K. (2000). Testing for stationarity in heterogeneous panel data. Econometrics Journal, 3(2), 148-161. https://doi.org/10.1111/1368-423X.00043

Hand, J. R., \& Landsman, W. R. (1998). Testing the Ohlson model: V or not V, that is the question. Working Paper, University of North Carolina. Retrieved from: https://papers.ssrn.com/sol3/papers.cfm?abstract_id=126308.

Im, K., Pesaran, M. H., \& Shin, Y. (2003). Testing for unit roots in heterogeneous panels. Journal of Econometrics, 115, 53-74. https://doi.org/10.1016/S0304-4076(03)00092-7

Johansen, S. (1991). Estimation and hypothesis testing of cointegration vectors in gaussian vector autoregressive models. Econometrica, 59(6), 1551-1580. https://doi.org/10.2307/2938278

Kao, C. (1999). Spurious Regression and Residual-Based Tests for Cointegration in Panel Data. Journal of Econometrics, 90, 1-44. https://doi.org/10.1016/S0304-4076(98)00023-2

Kargin, S. (2013). The Impact of IFRS on the Value Relevance of Accounting Information: Evidence from Turkish Firms. International Journal of Economics and Finance, 5(4), 71-80. https://doi.org/10.5539/ijef.v5n4p71

Lee, S. C., Chen, J. L., \& Tsa, M. S. (2014). An Empirical Investigation of the Ohlson Model - A Panel Cointegration Approach. Australasian Accounting, Business and Finance Journal, 8(2), 35-51. https://doi.org/10.14453/aabfj.v8i2.4

Lee, S. C., Lin, C. T., \& Yu, M. (2012). A fractional cointegration approach to testing the Ohlson accounting based valuation model. Review of Quantitative Finance and Accounting, 39(4). https://doi.org/10.1007/s11156-012-0321-0

Levin, L., Lin, C., \& Chu, (2002). Unit Root Tests in Panel Data: Asymptotic and Finite-Sample Properties. Journal of Econometrics, 108. https://doi.org/10.1016/S0304-4076(01)00098-7

Lima, A. N. (2008). Evidências empíricas do Modelo de Ohlson (1995) para o Brasil. (Doctoral dissertation). University of Vale do Rio dos Sinos, Brazil.

Lopes, A. B., Sant'anna, D. P., \& Costa, F. M. (2007). A relevâncias das informações contábeis na Bovespa a partir do arcabouço teórico de Ohlson: avaliação dos modelos de Residual Income Valuation e Abnormal Earnings Growt. Revista de Administração, 42(4), 497-510.

Maddala, G. S., \& Wu, S. (1999). A comparative study of unit root tests with panel data and a new simple test. Oxford Bulletin of Economics and Statistics, 61(Special issue), 631-652. https://doi.org/10.1111/1468-0084.0610s1631

Miller, M. H., \& Modigliani, F. (1966). Some Estimates of the Cost of Capital to the Electric Utility Industry, 1954-57. The American Economic Review, 56(3), 333-391.

Miranda, G. J., Reis, E. A., \& Lemes, S. (2006). Valor das Empresas: uma abordagem do fluxo de caixa descontado. Revista Contabilidade Vista e Revista, 17(3), 45-65.

Moura, A. A. F., \& Coelho, A. C. D. (2013). Value-Relevance de informações contábeis para instituições financeiras no Brasil. VII Congresso ANPCONT, Brazil.

Ohlson, J. A. (1991). The Theory of Value and Earnings, and an Introduction to the Ball-Brown Analysis. Contemporary Accounting Research, 8(1), 1-19. https://doi.org/10.1111/j.1911-3846.1991.tb00831.x

Ohlson, J. A. (1995). Earnings, book values and dividends in equity valuation. Contemporary Accounting Research, 11(2), 661-687. https://doi.org/10.1111/j.1911-3846.1995.tb00461.x 
Ohlson, J. A. (2001). .Earnings, Book Values, and Dividends in Equity Valuation: An Empirical Perspective. Contemporary Accounting Research, 18, 107-120. https://doi.org/10.1506/7TPJ-RXQN-TQC7-FFAE

Pedroni, P. (1999). Critical Values for Cointegration Tests in Heterogeneous Panels with Multiple Regressors. Oxford Bulletin of Economics and Statistics, 61(Special Issue), 653-678. https://doi.org/10.1111/1468-0084.0610s1653

Pesaran, M. (2004). General Diagnostic tests for cross section dependence in panels. CESifo working paper series. Retrieved from: https://www.repository.cam.ac.uk/handle/1810/446.

Qi, D. D., Wu, Y. W., \& Xiang, B. (2000). Stationarity and cointegration tests of the Ohlson model. Journal of Accounting, Auditing and Finance, 2, 141-160. https://doi.org/10.1177/0148558X0001500203

Rivera, E. B. B. R., Martin, D. M. L., Marçal, E. F., \& Basso, L. F. C. (2012). Modelo de valor presente entre preços e dividendos com retornos esperados constantes e variantes no tempo: evidências ao nível de empresa a partir da aplicação de painéis não estacionários. Brazilian Business Review, 9(4), 52-90.

Rocha, M., \& Barbi, F. (2009). Determinantes do Desalinhamento Cambial: Uma análise com cointegração em painel. Anais do XXXVII Encontro Nacional de Economia da ANPEC, Foz do Iguaçu, Brazil.

Scarpelli, M. C. (2010). Hysteresis nas exportações manufaturadas brasileiras: uma análise de cointegração com dados em painel (Doctoral dissertation). São Paulo University, São Pualo, Brazil.

Schuch, G. M. (2013). Modelo de Ohlson (1995) na Avaliação de Empresas: Uma Análise Empírica no Brasil. (Doctoral dissertation). Federal University of Rio Grande do Sul, Rio Grande do Sul, Brazil.

Song, C. J., Thomas, W. B., \& Yi, H. (2010). Value relevance of FAS 157 fair value hierarchy information and the impact of corporate governance mechanisms. The Accounting Review, 85(4), 1375-1410. https://doi.org/10.2308/accr.2010.85.4.1375

Sonza, I. B., \& Kloeckner, G. O. (2009). Co-integração entre o lucro contábil e o preço das ações negociadas pela Bovespa: um estudo empírico. Encontro Brasileiro de Finanças - Sociedade Brasileira de Finanças (SBFin), São Paulo, Brazil.

Suadiye, G. (2012). Value Relevance of Book Value \& Earnings under the Local GAAP and IFRS: Evidence from Turkey. Ege Akademik Review, 12(3), 301-310. https://doi.org/10.21121/eab.2012319519

Teixeira, A. A. E. (2017). Pair trading in Bovespa with a quantitative approach: cointegration, Ornstein-Uhlenbeck equation and Kelly criterion (Doctoral dissertation). FGV, Brazil.

Valdés, A. L., \& Vázquez. R. D. (2010). Ohlson model by panel cointegration with Mexican data. Revista Contaduría y Administración, 232, 131-142.

Vázquez. R. D., Valdés, A. L., \& Porras, A. R. (2011). Valuation of latin-american stock prices with alternative versions of the Ohlson model: an investigation of cointegration relationships with time-series and panel-data. MPRA Paper $\mathrm{n}^{\circ} 31359$.

\section{Appendix A}

Table 5. IPS (2003), Fisher ADF (1999) and LLC (2002) Tests

\begin{tabular}{ccccc}
\hline Variable & Basic Materials & Telecom. & Health & Oil, Gas and Bio. \\
\hline M.V. & & & & \\
\hline IPS & - & - & - & $-1.1749(0.1200)$ \\
\hline Fisher & - & - & - & $-1.2398(0.1075)$ \\
\hline LLC & - & - & - & $-1.7202(0.0427)$ \\
\hline$\Delta$ M.V. & & & & \\
\hline IPS & - & - & - & $-2.8381(0.0023)$ \\
\hline Fisher & - & - & - & $-5.5692(0.0000)$ \\
\hline LLC & - & - & - & $-7.0845(0.0000)$ \\
\hline B.V. & & & -1 & \\
\hline IPS & $-0.4566(0.3240)$ & $-1.2392(0.1076)$ & - & $-0.3118(0.3776)$ \\
\hline Fisher & $-0.4183(0.3379)$ & $-1.3028(0.0963)$ & - & $-0.0307(0.4877)$ \\
\hline LLC & $-8.1124(0.0000)$ & $-1.7046(0.0441)$ & - & $-1.3514(0.0883)$ \\
\hline$\Delta$ B.V. & & & & \\
\hline IPS & $-4.0725(0.0000)$ & $-2.9944(0.0014)$ & - & $-2.4336(0.0075)$ \\
\hline Fisher & $-7.1718(0.0000)$ & $-6.0032(0.0000)$ & - & $-4.5212(0.0000)$ \\
\hline LLC & $-2.2155(0.0134)$ & $-2.7028(0.0034)$ & - & $-1.6246(0.0521)$ \\
\hline
\end{tabular}




\section{Appendix A (Continuation)}

Table 5. IPS (2003), Fisher ADF (1999) e LLC (2002) Tests

Appendix B

\begin{tabular}{ccccc}
\hline Variable & Basic Materials & Telecom. & Health & Oil, Gas and Bio. \\
\hline A.E. & & & & \\
\hline IPS & - & - & $0.1352(0.5538)$ & $-0.2107(0.4166)$ \\
\hline Fisher & - & - & $0.5137(0.6963)$ & $-0.1503(0.4403)$ \\
\hline LLC & - & - & $-0.7541(0.2254)$ & $-1.4510(0.0734)$ \\
\hline$\Delta$ A.E. & & & & \\
\hline IPS & - & - & $-1.8716(0.0306)$ & $-2.1412(0.0161)$ \\
\hline Fisher & - & - & $-2.8177(0.0024)$ & $-3.4236(0.0003)$ \\
\hline LLC & - & - & $-1.1035(0.1349)$ & $-3.6789(0.0001)$ \\
\hline
\end{tabular}

Table 6. Hadri LM Test

\begin{tabular}{|c|c|c|c|c|c|c|c|c|c|}
\hline Variable & General & $\begin{array}{l}\text { Public } \\
\text { Utility }\end{array}$ & $\begin{array}{l}\text { Cyclical } \\
\text { cons. }\end{array}$ & $\begin{array}{c}\text { Basic } \\
\text { Materials }\end{array}$ & $\begin{array}{l}\text { Industrial } \\
\text { goods }\end{array}$ & $\begin{array}{l}\text { Non-cyclical } \\
\text { cons. }\end{array}$ & Telecom. & Health & Liquid \\
\hline \multicolumn{10}{|l|}{ M.V. } \\
\hline & $\begin{array}{l}18.3273 \\
(0.0000)\end{array}$ & $\begin{array}{c}8.6583 \\
(0.0000)\end{array}$ & $\begin{array}{l}10.2035 \\
(0.0000)\end{array}$ & $\begin{array}{c}7.1047 \\
(0.0000)\end{array}$ & $\begin{array}{c}5.8605 \\
(0.0000)\end{array}$ & $\begin{array}{c}5.1616 \\
(0.0000)\end{array}$ & $\begin{array}{c}4.4937 \\
(0.0000)\end{array}$ & $\begin{array}{c}5.0783 \\
(0.0000)\end{array}$ & $\begin{array}{l}14.6904 \\
(0.0000)\end{array}$ \\
\hline \multicolumn{10}{|l|}{$\Delta$ M.V. } \\
\hline & $\begin{array}{l}-1.9187^{*} \\
(0.9725) \\
\end{array}$ & $\begin{array}{c}-0.5367^{*} \\
(0.7043) \\
\end{array}$ & $\begin{array}{l}-1.8703^{*} \\
(0.9693) \\
\end{array}$ & $\begin{array}{l}-1.5185^{*} \\
(0.9356) \\
\end{array}$ & $\begin{array}{l}0.2076^{*} \\
(0.4178) \\
\end{array}$ & $\begin{array}{c}-0.4981 * \\
(0.6908) \\
\end{array}$ & $\begin{array}{c}-0.2552^{*} \\
(0.6007) \\
\end{array}$ & $\begin{array}{l}0.6960 * \\
(0.2432) \\
\end{array}$ & $\begin{array}{r}-1.9578^{*} \\
(0.9749) \\
\end{array}$ \\
\hline \multicolumn{10}{|l|}{ B.V. } \\
\hline & $\begin{array}{l}34.0833 \\
(0.0000) \\
\end{array}$ & $\begin{array}{l}17.1410 \\
(0.0000)\end{array}$ & $\begin{array}{l}19.4501 \\
(0.0000) \\
\end{array}$ & - & $\begin{array}{l}15.2417 \\
(0.0000) \\
\end{array}$ & $\begin{array}{c}7.4525 \\
(0.0000) \\
\end{array}$ & - & $\begin{array}{c}9.8704 \\
(0.0000)\end{array}$ & $\begin{array}{l}27.5844 \\
(0.0000) \\
\end{array}$ \\
\hline \multicolumn{10}{|l|}{$\Delta \mathrm{B} . \mathrm{V}$. } \\
\hline & $\begin{array}{l}1.5642 * \\
(0.0589) \\
\end{array}$ & $\begin{array}{l}-0.2318^{*} \\
(0.5917) \\
\end{array}$ & $\begin{array}{l}0.0731^{*} \\
(0.4709) \\
\end{array}$ & - & $\begin{array}{l}0.9193^{*} \\
(0.1790) \\
\end{array}$ & $\begin{array}{l}-0.4366^{*} \\
(0.6688) \\
\end{array}$ & - & $\begin{array}{l}-0.1153^{*} \\
(0.5459) \\
\end{array}$ & $\begin{array}{l}-0.1245^{*} \\
(0.5495) \\
\end{array}$ \\
\hline \multicolumn{10}{|l|}{ A.E. } \\
\hline & $\begin{array}{l}14.0172 \\
(0.0000)\end{array}$ & $\begin{array}{c}5.2763 \\
(0.0000)\end{array}$ & $\begin{array}{c}6.9194 \\
(0.0000)\end{array}$ & $\begin{array}{c}6.3201 \\
(0.0000)\end{array}$ & $\begin{array}{c}7.9192 \\
(0.0000)\end{array}$ & $\begin{array}{c}1.7295 \\
(0.0419)\end{array}$ & - & - & $\begin{array}{c}9.6978 \\
(0.0000)\end{array}$ \\
\hline \multicolumn{10}{|l|}{$\Delta$ A.E. } \\
\hline & $\begin{array}{l}0.6476^{*} \\
(0.2586)\end{array}$ & $\begin{array}{l}0.5456^{*} \\
(0.2927)\end{array}$ & $\begin{array}{l}0.5560 * \\
(0.2891)\end{array}$ & $\begin{array}{l}-2.3328 * \\
(0.9902)\end{array}$ & $\begin{array}{l}1.5790 * \\
(0.0572)\end{array}$ & $\begin{array}{l}1.5494^{*} \\
(0.0606)\end{array}$ & - & - & $\begin{array}{l}0.0793^{*} \\
(0.4684)\end{array}$ \\
\hline
\end{tabular}

Appendix C

Table 7. Pedroni (1999) Test

\begin{tabular}{|c|c|c|c|c|c|c|c|c|c|c|}
\hline Method & General & $\begin{array}{l}\text { Public } \\
\text { Utility }\end{array}$ & $\begin{array}{l}\text { Cyclical } \\
\text { cons. }\end{array}$ & $\begin{array}{c}\text { Basic } \\
\text { Material } \\
\mathbf{S}\end{array}$ & $\begin{array}{l}\text { Industri } \\
\text { al goods }\end{array}$ & $\begin{array}{l}\text { Non-cyclic } \\
\text { al cons. }\end{array}$ & $\begin{array}{c}\text { Telecom } \\
.\end{array}$ & Health & $\begin{array}{l}\text { Oil, Gas } \\
\text { and Bio. }\end{array}$ & Liquid \\
\hline \multicolumn{11}{|c|}{ Statistics within dimension } \\
\hline Panel v & $\begin{array}{c}-4.70317 \\
3 \\
(1.0000)\end{array}$ & $\begin{array}{c}0.58083 \\
8 \\
(0.2807)\end{array}$ & $\begin{array}{c}-2.78282 \\
4 \\
(0.9973)\end{array}$ & $\begin{array}{c}-2.01959 \\
1 \\
(0.9783)\end{array}$ & & $\begin{array}{c}2.873255 \\
(0.0020)\end{array}$ & $\begin{array}{c}-0.76825 \\
9 \\
(0.7788)\end{array}$ & $\begin{array}{c}4.114256 \\
(0.0000)\end{array}$ & $\begin{array}{c}1.46417 \\
4 \\
(0.0716)\end{array}$ & $\begin{array}{c}5.15275 \\
4 \\
(0.0000)\end{array}$ \\
\hline Panel rho & $\begin{array}{c}0.78127 \\
1 \\
(0.7827)\end{array}$ & $\begin{array}{c}0.17716 \\
6 \\
(0.5703)\end{array}$ & $\begin{array}{c}-1.38425 \\
7 \\
(0.0831)\end{array}$ & $\begin{array}{c}0.251137 \\
(0.5991)\end{array}$ & $\begin{array}{c}0.329612 \\
(0.6292)\end{array}$ & $\begin{array}{c}-0.278664 \\
(0.3903)\end{array}$ & $\begin{array}{c}1.48715 \\
2 \\
(0.9315)\end{array}$ & $\begin{array}{c}0.91530 \\
1 \\
(0.8200)\end{array}$ & $\begin{array}{c}-0.32412 \\
5 \\
(0.3729)\end{array}$ & $\begin{array}{c}1.35425 \\
4 \\
(0.9122)\end{array}$ \\
\hline Panel & $\begin{array}{c}-3.754 \\
1 \\
(0.000\end{array}$ & $\begin{array}{c}-3.62025 \\
7 \\
(0.0001)\end{array}$ & $\begin{array}{c}-8.26170 \\
9 \\
(0.0000)\end{array}$ & $\begin{array}{c}-1.62009 \\
1 \\
(0.0526)\end{array}$ & $\begin{array}{c}-2.01386 \\
2 \\
(0.0220)\end{array}$ & $\begin{array}{c}-5.911053 \\
(0.0000)\end{array}$ & $\begin{array}{c}1.62901 \\
6 \\
(0.9483)\end{array}$ & $\begin{array}{c}-0.49907 \\
0 \\
(0.3089)\end{array}$ & $\begin{array}{c}-3.98476 \\
4 \\
(0.0000)\end{array}$ & $\begin{array}{c}-6.14582 \\
8 \\
(0.0000)\end{array}$ \\
\hline $\begin{array}{l}\text { Panel } \\
\text { ADF }\end{array}$ & $\begin{array}{c}-3.83320 \\
2 \\
(0.0001) \\
\end{array}$ & $\begin{array}{c}-4.76437 \\
1 \\
(0.0000) \\
\end{array}$ & $\begin{array}{c}-8.22032 \\
9 \\
(0.0000) \\
\end{array}$ & $\begin{array}{c}-1.62032 \\
4 \\
(0.0526) \\
\end{array}$ & $\begin{array}{c}-2.02098 \\
2 \\
(0.0216) \\
\end{array}$ & & $\begin{array}{c}1.62165 \\
4 \\
(0.9476) \\
\end{array}$ & $\begin{array}{c}-3.97598 \\
0 \\
(0.0000) \\
\end{array}$ & $\begin{array}{c}-4.32073 \\
2 \\
(0.0000) \\
\end{array}$ & $\begin{array}{c}-11.5162 \\
9 \\
(0.0000) \\
\end{array}$ \\
\hline \multicolumn{11}{|c|}{ Statistics between dimensions } \\
\hline Group rho & $\begin{array}{c}3.89332 \\
0 \\
(1.0000)\end{array}$ & $\begin{array}{c}2.40496 \\
8 \\
(0.9919)\end{array}$ & $\begin{array}{c}0.93184 \\
3 \\
(0.8243)\end{array}$ & $\begin{array}{c}0.775325 \\
(0.7809)\end{array}$ & $\begin{array}{c}1.896067 \\
(0.9710)\end{array}$ & $\begin{array}{c}0.646765 \\
(0.7411)\end{array}$ & $\begin{array}{c}2.02005 \\
2 \\
(0.9783)\end{array}$ & $\begin{array}{c}1.54925 \\
9 \\
(0.9393)\end{array}$ & $\begin{array}{c}1.00103 \\
7 \\
(0.8416)\end{array}$ & $\begin{array}{c}2.33935 \\
1 \\
(0.9903)\end{array}$ \\
\hline Group pp & $\begin{array}{c}-15.3193 \\
5 \\
(0.0000)\end{array}$ & $\begin{array}{c}-3.87326 \\
6 \\
(0.0001)\end{array}$ & $\begin{array}{c}-14.0769 \\
1 \\
(0.0000)\end{array}$ & $\begin{array}{c}-5.78016 \\
6 \\
(0.0000)\end{array}$ & $\begin{array}{c}-5.90475 \\
5 \\
(0.0000)\end{array}$ & $\begin{array}{c}-6.550126 \\
(0.0000)\end{array}$ & $\begin{array}{c}0.58756 \\
1 \\
(0.7216)\end{array}$ & $\begin{array}{c}-0.81781 \\
5 \\
(0.2067)\end{array}$ & $\begin{array}{c}-3.68196 \\
9 \\
(0.0001)\end{array}$ & $\begin{array}{c}-13.4042 \\
1 \\
(0.0000)\end{array}$ \\
\hline $\begin{array}{l}\text { Group } \\
\text { ADF }\end{array}$ & $\begin{array}{c}-13.4584 \\
3 \\
(0.0000) \\
\end{array}$ & $\begin{array}{c}-4.85385 \\
2 \\
(0.0000)\end{array}$ & $\begin{array}{c}-8.84907 \\
1 \\
(0.0000)\end{array}$ & $\begin{array}{c}-5.29541 \\
3 \\
(0.0000)\end{array}$ & $\begin{array}{c}-4.49621 \\
0 \\
(0.0000)\end{array}$ & $\begin{array}{c}-5.262943 \\
(0.0000)\end{array}$ & $\begin{array}{c}-1.66802 \\
3 \\
(0.0477) \\
\end{array}$ & $\begin{array}{c}-3.21269 \\
0 \\
(0.0007)\end{array}$ & $\begin{array}{c}-3.82938 \\
3 \\
(0.0001)\end{array}$ & $\begin{array}{c}-11.4400 \\
5 \\
(0.0000) \\
\end{array}$ \\
\hline
\end{tabular}




\section{Appendix D}

Table 8. Kao (1999) Test

\begin{tabular}{|c|c|c|c|c|c|c|c|c|c|}
\hline General & $\begin{array}{l}\text { Public } \\
\text { Utility } \\
\end{array}$ & $\begin{array}{l}\text { Cyclical } \\
\text { cons. }\end{array}$ & $\begin{array}{c}\text { Basic } \\
\text { Materials }\end{array}$ & $\begin{array}{c}\text { Industrial } \\
\text { goods }\end{array}$ & $\begin{array}{c}\text { Non-cyclical } \\
\text { cons. }\end{array}$ & Telecom. & Health & $\begin{array}{l}\text { Oil, Gas } \\
\text { and Bio. }\end{array}$ & Liquid \\
\hline $\begin{array}{c}-17.06850 \\
(0.0000)\end{array}$ & $\begin{array}{c}-4.422519 \\
(0.0000)\end{array}$ & $\begin{array}{c}-2.999696 \\
(0.0014)\end{array}$ & $\begin{array}{c}-5.989815 \\
(0.0000)\end{array}$ & $\begin{array}{c}-6.290448 \\
(0.0000)\end{array}$ & $\begin{array}{c}-0.924668 \\
(0.1776)\end{array}$ & $\begin{array}{c}-0.575082 \\
(0.2826)\end{array}$ & $\begin{array}{c}-4.509824 \\
(0.0000)\end{array}$ & $\begin{array}{c}-3.014507 \\
(0.0013)\end{array}$ & $\begin{array}{l}2.841891 \\
(0.0022)\end{array}$ \\
\hline
\end{tabular}

\section{Appendix E}

Table 9. Estimation by DOLS in Panel

\begin{tabular}{cccccccccc}
\hline \multirow{2}{*}{ Variable } & \multirow{2}{*}{ General } & $\begin{array}{c}\text { Public } \\
\text { Utility }\end{array}$ & $\begin{array}{c}\text { Cyclical } \\
\text { cons. }\end{array}$ & $\begin{array}{c}\text { Basic } \\
\text { Materials }\end{array}$ & $\begin{array}{c}\text { Industrial } \\
\text { goods }\end{array}$ & $\begin{array}{c}\text { Non-cyclical } \\
\text { cons. }\end{array}$ & Health & $\begin{array}{c}\text { Oil, Gas } \\
\text { and Bio. }\end{array}$ & Liquid \\
\hline \multirow{2}{*}{ Book Value } & $2202.097 *$ & $1314.052^{*}$ & $3125.784 *$ & $2585.067 *$ & 1259.876 & 9463.963 & -1098.758 & $2162.034 *$ & $2216.194 *$ \\
& $(0.0000)$ & $(0.0000)$ & $(0.0000)$ & $(0.0002)$ & $(0.2459)$ & $(0.0978)$ & $(0.6547)$ & $(0.0001)$ & $(0.0000)$ \\
\hline Abnormal & $5453.921 *$ & $5181.609 *$ & $8553.421 *$ & 9177.865 & 4519.763 & 16292.21 & -33473.06 & 4427.252 & 2274.000 \\
Earning & $(0.0038)$ & $(0.0000)$ & $(0.0363)$ & $(0.1417)$ & $(0.4223)$ & $(0.1279)$ & $(0.1548)$ & $(0.0711)$ & $(0.3461)$ \\
\hline
\end{tabular}

\section{Appendix F}

Table 10. Sub-sample (Most liquid companies in B3)

\begin{tabular}{|c|c|}
\hline Code & Company \\
\hline ABEV3 & AMBEV S.A. \\
\hline AELP3 & AES ELPA S.A. \\
\hline ALPA3 & ALPARGATAS S.A. \\
\hline BRAP3 & BRADESPAR S.A. \\
\hline BRFS3 & BRF S.A. \\
\hline BRKM3 & BRASKEM S.A. \\
\hline CESP3 & CESP - CIA ENERGETICA DE SAO PAULO \\
\hline CGAS3 & CIA GAS DE SAO PAULO - COMGAS \\
\hline CGRA3 & GRAZZIOTIN S.A. \\
\hline CLSC3 & CENTRAIS ELET DE SANTA CATARINA S.A. \\
\hline CMIG3 & CIA ENERGETICA DE MINAS GERAIS - CEMIG \\
\hline COCE3 & CIA ENERGETICA DO CEARA - COELCE \\
\hline CPFE3 & CPFL ENERGIA S.A. \\
\hline CPLE3 & CIA PARANAENSE DE ENERGIA - COPEL \\
\hline CSNA3 & CIA SIDERURGICA NACIONAL \\
\hline CTNM3 & CIA TECIDOS NORTE DE MINAS COTEMINAS \\
\hline DASA3 & DIAGNOSTICOS DA AMERICA S.A. \\
\hline EGIE3 & ENGIE BRASIL ENERGIA S.A. \\
\hline ELET3 & CENTRAIS ELET BRAS S.A. - ELETROBRAS \\
\hline EMBR3 & EMBRAER S.A. \\
\hline ETER3 & ETERNIT S.A. \\
\hline FESA3 & CIA FERRO LIGAS DA BAHIA - FERBASA \\
\hline FIBR3 & FIBRIA CELULOSE S.A. \\
\hline GGBR3 & GERDAU S.A. \\
\hline GOAU3 & METALURGICA GERDAU S.A. \\
\hline GRND3 & GRENDENE S.A. \\
\hline GUAR3 & GUARARAPES CONFECCOES S.A. \\
\hline KLBN3 & KLABIN S.A. \\
\hline LAME3 & LOJAS AMERICANAS S.A. \\
\hline LEVE3 & MAHLE-METAL LEVE S.A. \\
\hline NATU3 & NATURA COSMETICOS S.A. \\
\hline PCAR3 & CIA BRASILEIRA DE DISTRIBUICAO \\
\hline PETR3 & PETROLEO BRASILEIRO S.A. PETROBRAS \\
\hline
\end{tabular}




\section{Appendix F (Continuation)}

Table 10. Sub-sample (Most liquid companies in B3)

\begin{tabular}{c|l}
\hline Code & \multicolumn{1}{c}{ Company } \\
\hline PNVL3 & DIMED S.A. DISTRIBUIDORA DE MEDICAMENTOS \\
\hline POMO3 & MARCOPOLO S.A. \\
\hline RAPT3 & RANDON S.A. IMPLEMENTOS E PARTICIPACOES \\
\hline SAPR3 & CIA SANEAMENTO DO PARANA - SANEPAR \\
\hline SBSP3 & CIA SANEAMENTO BASICO EST SAO PAULO \\
\hline SLED3 & SARAIVA S.A. LIVREIROS EDITORES \\
\hline TRPL3 & CTEEP - CIA TRANSMISSÃO ENERGIA ELETRICA PAULISTA \\
\hline UGPA3 & ULTRAPAR PARTICIPACOES S.A. \\
\hline UNIP3 & UNIPAR CARBOCLORO S.A. \\
\hline USIM3 & USINAS SID DE MINAS GERAIS S.A.-USIMINAS \\
\hline VALE3 & VALE S.A. \\
\hline WEGE3 & WEG S.A.
\end{tabular}

\section{Appendix G}

Table 11. Unit Root Tests

\begin{tabular}{|c|c|c|c|c|c|c|}
\hline Company & M.V. & $\Delta$ M.V. & B.V. & $\Delta$ B.V. & A.E. & $\Delta$ A.E. \\
\hline \multicolumn{7}{|l|}{ Ambev } \\
\hline $\mathrm{ADF}$ & $\begin{array}{c}-1.824657 \\
(0.3509)\end{array}$ & $\begin{array}{c}-3.221445 \\
(0.0494)\end{array}$ & $\begin{array}{c}-2.064040 \\
(0.2597)\end{array}$ & $\begin{array}{c}-2.692271 \\
(0.1085)\end{array}$ & $\begin{array}{c}-1.932072 \\
(0.3067)\end{array}$ & $\begin{array}{c}-1.819826 \\
(0.3513)\end{array}$ \\
\hline PP & $\begin{array}{c}-1.826667 \\
(0.3501)\end{array}$ & $\begin{array}{c}-3.231834 \\
(0.0486)\end{array}$ & $\begin{array}{c}-2.101227 \\
(0.2471)\end{array}$ & $\begin{array}{c}-2.691502 \\
(0.1087)\end{array}$ & $\begin{array}{c}-2.186950 \\
(0.2200)\end{array}$ & $\begin{array}{c}-1.775509 \\
(0.3694)\end{array}$ \\
\hline KPSS & 0.251935 & 0.198003 & 0.159421 & 0.138072 & 0.236912 & 0.324232 \\
\hline \multicolumn{7}{|l|}{ Aes Elpa } \\
\hline $\mathrm{ADF}$ & $\begin{array}{c}-1.555404 \\
(0.4702)\end{array}$ & $\begin{array}{c}-3.036681 \\
(0.0651)\end{array}$ & $\begin{array}{c}-4.094938 \\
(0.0118)\end{array}$ & $\begin{array}{c}-4.657513 \\
(0.0060)\end{array}$ & $\begin{array}{c}-1.751305 \\
(0.3819)\end{array}$ & $\begin{array}{c}-4.065479 \\
(0.0140)\end{array}$ \\
\hline PP & $\begin{array}{c}-1.622382 \\
(0.4394)\end{array}$ & $\begin{array}{c}-3.036681 \\
(0.0651)\end{array}$ & $\begin{array}{c}-5.811780 \\
(0.0010)\end{array}$ & $\begin{array}{c}-5.326431 \\
(0.0025)\end{array}$ & $\begin{array}{c}-1.817114 \\
(0.3540)\end{array}$ & $\begin{array}{c}-4.052239 \\
(0.0143) \\
\end{array}$ \\
\hline KPSS & 0.178330 & 0.158021 & 0.360715 & 0.280247 & 0.251612 & 0.160481 \\
\hline \multicolumn{7}{|l|}{ Alpargatas } \\
\hline $\mathrm{ADF}$ & $\begin{array}{c}-1.656101 \\
(0.4240)\end{array}$ & $\begin{array}{c}-3.017116 \\
(0.0670) \\
\end{array}$ & $\begin{array}{c}-0.387013 \\
(0.8799) \\
\end{array}$ & $\begin{array}{c}-3.505780 \\
(0.0323) \\
\end{array}$ & $\begin{array}{c}-1.909914 \\
(0.3163)\end{array}$ & $\begin{array}{c}-2.965660 \\
(0.0723) \\
\end{array}$ \\
\hline PP & $\begin{array}{c}-1.598153 \\
(0.4505)\end{array}$ & $\begin{array}{c}-3.590996 \\
(0.0284)\end{array}$ & $\begin{array}{c}-0.361795 \\
(0.8846)\end{array}$ & $\begin{array}{c}-3.505780 \\
(0.0323)\end{array}$ & $\begin{array}{c}-1.909914 \\
(0.3163)\end{array}$ & $\begin{array}{c}-2.958992 \\
(0.0731)\end{array}$ \\
\hline KPSS & 0.367479 & 0.500000 & 0.504626 & 0.124616 & 0.147482 & 0.105317 \\
\hline \multicolumn{7}{|l|}{ Bradespar } \\
\hline $\mathrm{ADF}$ & $\begin{array}{c}-2.068261 \\
(0.2583)\end{array}$ & $\begin{array}{c}-4.324742 \\
(0.0096)\end{array}$ & $\begin{array}{c}-1.580206 \\
(0.4588) \\
\end{array}$ & $\begin{array}{c}-3.145083 \\
(0.0553) \\
\end{array}$ & $\begin{array}{c}-1.872344 \\
(0.3312)\end{array}$ & $\begin{array}{c}-4.486740 \\
(0.0076)\end{array}$ \\
\hline PP & $\begin{array}{c}-2.069976 \\
(0.2577)\end{array}$ & $\begin{array}{c}-4.754545 \\
(0.0052) \\
\end{array}$ & $\begin{array}{c}-1.633339 \\
(0.4344)\end{array}$ & $\begin{array}{c}-3.148891 \\
(0.0550) \\
\end{array}$ & $\begin{array}{c}-1.840610 \\
(0.3443)\end{array}$ & $\begin{array}{c}-4.469222 \\
(0.0078) \\
\end{array}$ \\
\hline KPSS & 0.287873 & 0.398318 & 0.425302 & 0.173450 & 0.325028 & 0.141515 \\
\hline \multicolumn{7}{|l|}{ BRF } \\
\hline $\mathrm{ADF}$ & $\begin{array}{c}-0.938307 \\
(0.7345)\end{array}$ & $\begin{array}{c}-2.964382 \\
(0.0725)\end{array}$ & $\begin{array}{c}-1.303505 \\
(0.5876) \\
\end{array}$ & $\begin{array}{c}-3.683781 \\
(0.0247) \\
\end{array}$ & $\begin{array}{c}-2.698322 \\
(0.1076)\end{array}$ & $\begin{array}{c}-2.260549 \\
(0.2010) \\
\end{array}$ \\
\hline PP & $\begin{array}{c}-0.933016 \\
(0.7363)\end{array}$ & $\begin{array}{c}-2.970251 \\
(0.0719) \\
\end{array}$ & $\begin{array}{c}-1.204242 \\
(0.6313)\end{array}$ & $\begin{array}{c}-3.786710 \\
(0.0212) \\
\end{array}$ & $\begin{array}{c}-3.562569 \\
(0.0272)\end{array}$ & $\begin{array}{c}-1.863253 \\
(0.3335) \\
\end{array}$ \\
\hline KPSS & 0.436835 & 0.135352 & 0.423474 & 0.210035 & 0.380862 & 0.194133 \\
\hline
\end{tabular}




\section{Appendix G}

Table 11. Unit Root Tests

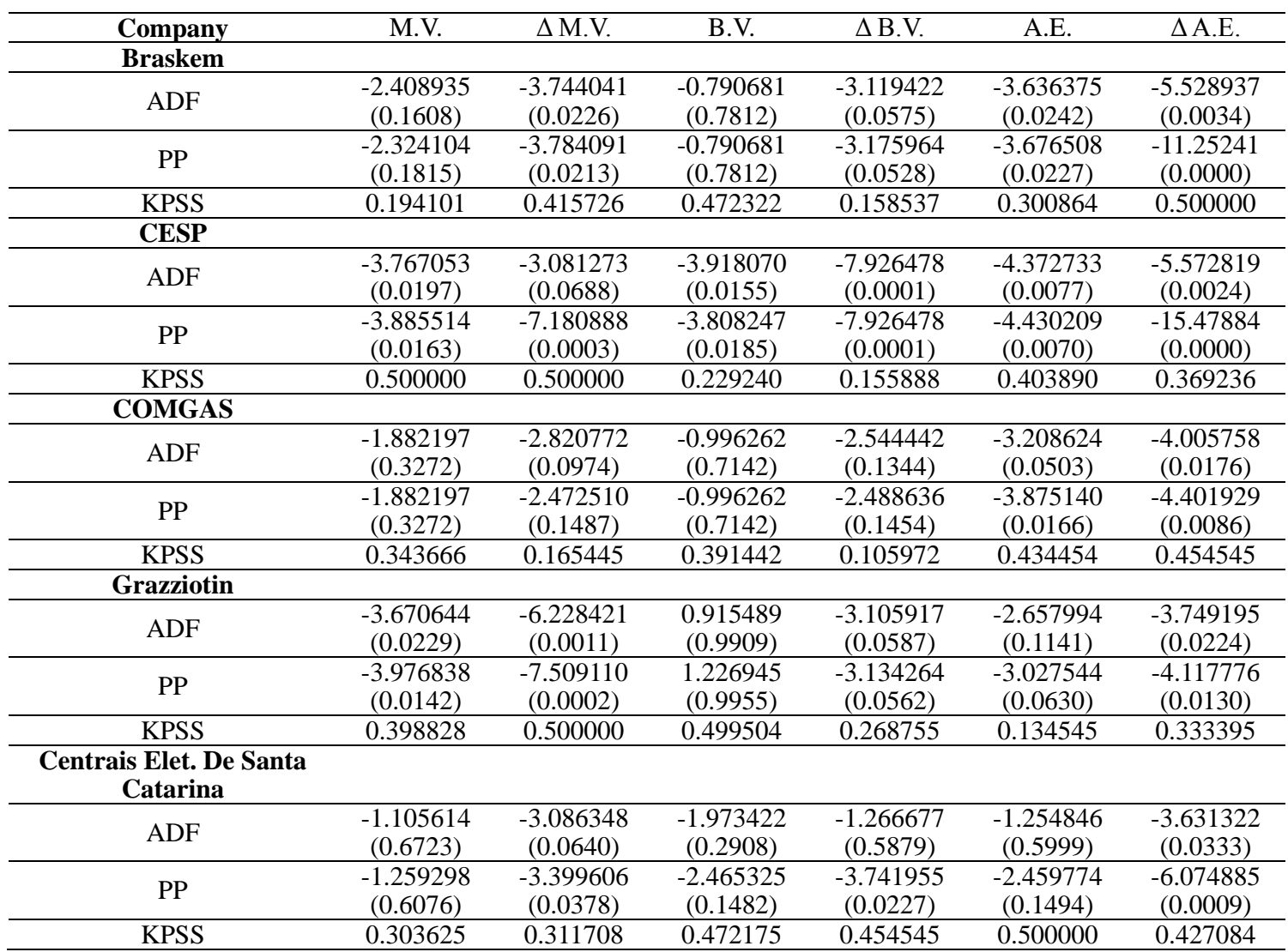

\section{Appendix G}

Table 11. Unit Root Tests

\begin{tabular}{|c|c|c|c|c|c|c|}
\hline Company & M.V. & $\Delta \mathrm{M} . \mathrm{V}$. & B.V. & $\Delta \mathrm{B} . \mathrm{V}$. & A.E. & $\Delta$ A.E. \\
\hline \multicolumn{7}{|l|}{ Cemig } \\
\hline $\mathrm{ADF}$ & $\begin{array}{c}-2.071889 \\
(0.2570)\end{array}$ & $\begin{array}{c}-3.727964 \\
(0.0231)\end{array}$ & $\begin{array}{c}-0.026847 \\
(0.9307)\end{array}$ & $\begin{array}{c}-3.944802 \\
(0.0222)\end{array}$ & $\begin{array}{c}-0.882939 \\
(0.7528)\end{array}$ & $\begin{array}{c}-1.529630 \\
(0.4787)\end{array}$ \\
\hline PP & $\begin{array}{c}-2.108231 \\
(0.2448)\end{array}$ & $\begin{array}{c}-3.741435 \\
(0.0227)\end{array}$ & $\begin{array}{c}0.345679 \\
(0.9687)\end{array}$ & $\begin{array}{c}-13.24406 \\
(0.0000)\end{array}$ & $\begin{array}{c}-0.882939 \\
(0.7528)\end{array}$ & $\begin{array}{c}-1.529630 \\
(0.4787)\end{array}$ \\
\hline KPSS & 0.171024 & 0.277728 & 0.491602 & 0.454545 & 0.129468 & 0.317318 \\
\hline \multicolumn{7}{|l|}{ Coelce } \\
\hline $\mathrm{ADF}$ & $\begin{array}{c}-1.454450 \\
(0.5176)\end{array}$ & $\begin{array}{c}-4.903402 \\
(0.0043)\end{array}$ & $\begin{array}{l}1.311643 \\
(0.9963)\end{array}$ & $\begin{array}{c}-2.074799 \\
(0.2561)\end{array}$ & $\begin{array}{c}2.269872 \\
(0.1960)\end{array}$ & $\begin{array}{c}-3.699757 \\
(0.0241)\end{array}$ \\
\hline PP & $\begin{array}{c}-1.260688 \\
(0.6069)\end{array}$ & $\begin{array}{c}-8.542832 \\
(0.0001)\end{array}$ & $\begin{array}{c}1.380337 \\
(0.9968)\end{array}$ & $\begin{array}{c}-1.884927 \\
(0.3249)\end{array}$ & $\begin{array}{c}-2.304086 \\
(0.1867)\end{array}$ & $\begin{array}{c}-3.685418 \\
(0.0247)\end{array}$ \\
\hline KPSS & 0.498986 & 0.500000 & 0.482369 & 0.420222 & 0.137707 & 0.227553 \\
\hline \multicolumn{7}{|c|}{ CPFL Energia } \\
\hline $\mathrm{ADF}$ & $\begin{array}{c}-1.685473 \\
(0.4109)\end{array}$ & $\begin{array}{c}-2.537317 \\
(0.1358)\end{array}$ & $\begin{array}{c}0.174179 \\
(0.9561)\end{array}$ & $\begin{array}{c}-3.596900 \\
(0.0281)\end{array}$ & $\begin{array}{c}0.255250 \\
(0.9609)\end{array}$ & $\begin{array}{c}-0.842152 \\
(0.7492)\end{array}$ \\
\hline PP & $\begin{array}{c}-1.611063 \\
(0.4445)\end{array}$ & $\begin{array}{c}-2.398379 \\
(0.1650)\end{array}$ & $\begin{array}{l}1.153311 \\
(0.9947)\end{array}$ & $\begin{array}{c}-3.596900 \\
(0.0281)\end{array}$ & $\begin{array}{c}-0.557005 \\
(0.8432)\end{array}$ & $\begin{array}{c}-4.111817 \\
(0.0131)\end{array}$ \\
\hline KPSS & 0.361376 & 0.115279 & 0.490021 & 0.356099 & 0.355511 & 0.426276 \\
\hline Copel & & & & & & \\
\hline $\mathrm{ADF}$ & $\begin{array}{c}-2.219029 \\
(0.2105)\end{array}$ & $\begin{array}{c}-3.397380 \\
(0.0379)\end{array}$ & $\begin{array}{c}-0.745741 \\
(0.7942)\end{array}$ & $\begin{array}{c}-2.884966 \\
(0.0815)\end{array}$ & $\begin{array}{c}2.200192 \\
(0.9993)\end{array}$ & $\begin{array}{c}-6.685802 \\
(0.0004)\end{array}$ \\
\hline PP & $\begin{array}{c}-2.219029 \\
(0.2105)\end{array}$ & $\begin{array}{c}-3.424632 \\
(0.0364)\end{array}$ & $\begin{array}{c}-1.333980 \\
(0.5736)\end{array}$ & $\begin{array}{c}-3.761067 \\
(0.0220)\end{array}$ & $\begin{array}{c}-0.643599 \\
(0.8217)\end{array}$ & $\begin{array}{c}-6.170812 \\
(0.0008)\end{array}$ \\
\hline KPSS & 0.165525 & 0.318770 & 0.511725 & 0.500000 & 0.402749 & 0.403435 \\
\hline \multicolumn{7}{|c|}{ Cia Siderurgica Nacional } \\
\hline $\mathrm{ADF}$ & $\begin{array}{c}-2.036893 \\
(0.2691)\end{array}$ & $\begin{array}{c}-3.989278 \\
(0.0157)\end{array}$ & $\begin{array}{c}-3.055046 \\
(0.0633)\end{array}$ & $\begin{array}{c}-4.112611 \\
(0.0152)\end{array}$ & $\begin{array}{c}-1.119839 \\
(0.6666)\end{array}$ & $\begin{array}{c}-2.892113 \\
(0.0884)\end{array}$ \\
\hline PP & $\begin{array}{c}-2.023261 \\
(0.2739)\end{array}$ & $\begin{array}{c}-4.056413 \\
(0.0142)\end{array}$ & $\begin{array}{c}-3.418539 \\
(0.0341)\end{array}$ & $\begin{array}{c}-5.591251 \\
(0.0017)\end{array}$ & $\begin{array}{c}-1.068949 \\
(0.6867)\end{array}$ & $\begin{array}{c}-3.869477 \\
(0.0187)\end{array}$ \\
\hline KPSS & 0.247165 & 0.256776 & 0.175021 & 0.333923 & 0.340980 & 0.500000 \\
\hline
\end{tabular}




\section{Appendix G}

Table 11. Unit Root Tests

\begin{tabular}{ccccccc}
\hline Company & M.V. & $\Delta$ M.V. & B.V. & $\Delta$ B.V. & A.E. & $\Delta$ A.E. \\
\hline Coteminas & & & & & & \\
\hline \multirow{2}{*}{ ADF } & -3.183822 & -4.191477 & -0.201347 & -2.735894 & -3.884986 & -4.280204 \\
& $(0.0557)$ & $(0.0136)$ & $(0.9120)$ & $(0.1018)$ & $(0.0183)$ & $(0.0145)$ \\
\hline \multirow{2}{*}{ PP } & -0.947079 & -4.191749 & -0.264522 & -2.735894 & -4.379657 & -6.635745 \\
& $(0.7315)$ & $(0.0116)$ & $(0.9019)$ & $(0.1018)$ & $(0.0076)$ & $(0.0005)$ \\
\hline KPSS & 0.474482 & 0.375786 & 0.381428 & 0.307992 & 0.500000 & 0.409681 \\
\hline Diagnosticos da & & & & & & \\
America & -2.524304 & -3.532092 & -0.666029 & -3.457383 & -0.805695 & -3.719020 \\
ADF & $(0.1383)$ & $(0.0341)$ & $(0.8159)$ & $(0.0347)$ & $(0.7767)$ & $(0.0234)$ \\
\hline \multirow{2}{*}{ PP } & -1.728060 & -2.922911 & -0.553942 & -3.631392 & -0.726071 & -3.716450 \\
& $(0.3921)$ & $(0.0771)$ & $(0.8440)$ & $(0.0267)$ & $(0.7997)$ & $(0.0235)$ \\
\hline KPSS & 0.180664 & 0.500000 & 0.461176 & 0.203059 & 0.339598 & 0.211383 \\
\hline Engie Brasil Energia & & & & & & \\
\hline \multirow{2}{*}{ ADF } & -1.258639 & -2.622962 & 0.125161 & -3.652131 & -2.453156 & -2.530279 \\
& $(0.6078)$ & $(0.1201)$ & $(0.9517)$ & $(0.0324)$ & $(0.1509)$ & $(0.1371)$ \\
\hline PP & -1.356534 & -2.582598 & 0.143922 & -2.836087 & -2.453156 & -2.522255 \\
& $(0.5632)$ & $(0.1273)$ & $(0.9534)$ & $(0.0877)$ & $(0.1509)$ & $(0.1387)$ \\
\hline KPSS & 0.480909 & 0.239435 & 0.500107 & 0.115271 & 0.220628 & 0.489722 \\
\hline Eletrobras & \multicolumn{7}{c}{} & & \\
\hline \multirow{2}{*}{ ADF } & -1.371724 & -2.324211 & 0.230944 & -4.273816 & -3.117705 & -1.576180 \\
& $(0.5563)$ & $(0.1828)$ & $(0.9590)$ & $(0.0103)$ & $(0.0547)$ & $(0.4485)$ \\
\hline \multirow{2}{*}{ PP } & -1.433700 & -2.335365 & -0.103085 & -4.320842 & -3.114734 & -4.986140 \\
& $(0.5274)$ & $(0.1800)$ & $(0.9261)$ & $(0.0097)$ & $(0.0550)$ & $(0.0038)$ \\
\hline KPSS & 0.272921 & 0.160698 & 0.454909 & 0.217308 & 0.143074 & 0.185543 \\
\hline Embraer & -2.068884 & -5.641979 & 2.444008 & -5.981708 & -0.462249 & -3.461318 \\
\hline \multirow{2}{*}{ ADF } & $(0.2581)$ & $(0.0016)$ & $(0.9996)$ & $(0.0011)$ & $(0.8646)$ & $(0.0345)$ \\
\hline \multirow{2}{*}{ PP } & -5.535972 & -5.927949 & -2.560553 & -6.018297 & -0.398417 & -3.488538 \\
& $(0.0014)$ & $(0.0011)$ & $(0.1290)$ & $(0.0010)$ & $(0.8777)$ & $(0.0331)$ \\
\hline KPSS & 0.207440 & 0.349238 & 0.246971 & 0.478663 & 0.551558 & 0.221848 \\
\hline & & & & &
\end{tabular}




\section{Appendix G}

Table 11. Unit Root Tests

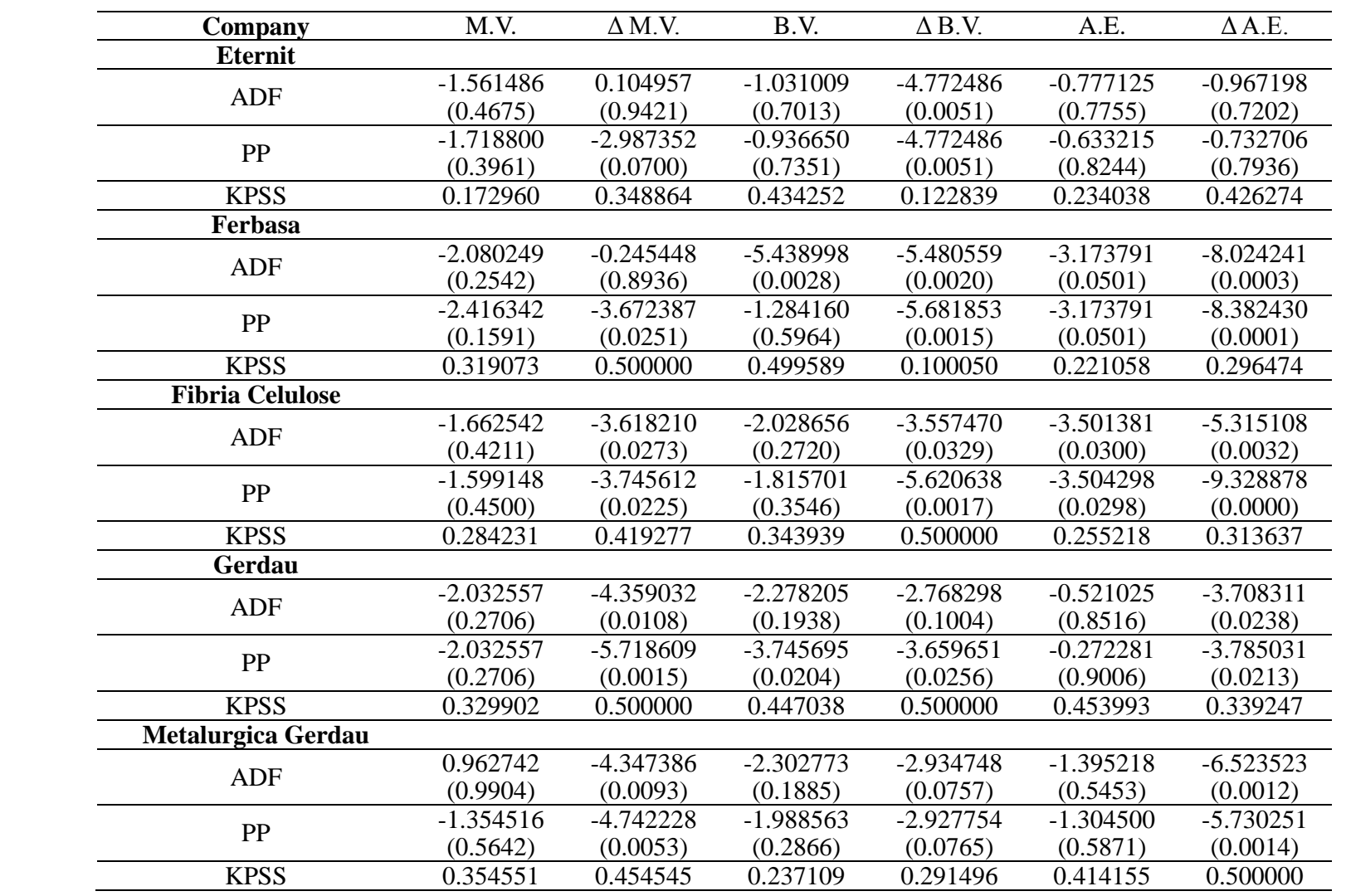

\section{Appendix G}

Table 11. Unit Root Tests

\begin{tabular}{|c|c|c|c|c|c|c|}
\hline Company & M.V. & $\Delta$ M.V. & B.V. & $\Delta$ B.V. & A.E. & $\Delta$ A.E. \\
\hline \multicolumn{7}{|l|}{ Grendene } \\
\hline $\mathrm{ADF}$ & $\begin{array}{c}-0.948292 \\
(0.7311)\end{array}$ & $\begin{array}{c}-3.675701 \\
(0.0278)\end{array}$ & $\begin{array}{c}1.263278 \\
(0.9955)\end{array}$ & $\begin{array}{c}0.022746 \\
(0.9390)\end{array}$ & $\begin{array}{c}-1.611909 \\
(0.4441)\end{array}$ & $\begin{array}{c}-4.856679 \\
(0.0045)\end{array}$ \\
\hline $\mathrm{PP}$ & $\begin{array}{c}-0.420328 \\
(0.8733)\end{array}$ & $\begin{array}{c}-6.000982 \\
(0.0010)\end{array}$ & $\begin{array}{c}1.860862 \\
(0.9989)\end{array}$ & $\begin{array}{c}0.004341 \\
(0.9370)\end{array}$ & $\begin{array}{c}-1.961128 \\
(0.2967)\end{array}$ & $\begin{array}{c}-7.269356 \\
(0.0002)\end{array}$ \\
\hline KPSS & 0.451231 & 0.408519 & 0.521164 & 0.317504 & 0.489453 & 0.500000 \\
\hline \multicolumn{7}{|c|}{ Guararapes Confecções } \\
\hline $\mathrm{ADF}$ & $\begin{array}{c}-2.407555 \\
(0.1629)\end{array}$ & $\begin{array}{c}-3.261467 \\
(0.0465)\end{array}$ & $\begin{array}{c}0.623970 \\
(0.9826)\end{array}$ & $\begin{array}{c}-2.687569 \\
(0.1093)\end{array}$ & $\begin{array}{c}-1.322045 \\
(0.5791)\end{array}$ & $\begin{array}{c}-2.954481 \\
(0.0736)\end{array}$ \\
\hline $\mathrm{PP}$ & $\begin{array}{c}-2.013525 \\
(0.2774)\end{array}$ & $\begin{array}{c}-3.268437 \\
(0.0460)\end{array}$ & $\begin{array}{c}0.720671 \\
(0.9859)\end{array}$ & $\begin{array}{c}-2.657017 \\
(0.1143)\end{array}$ & $\begin{array}{c}-1.322045 \\
(0.5791)\end{array}$ & $\begin{array}{c}-2.954481 \\
(0.0736)\end{array}$ \\
\hline $\begin{array}{c}\text { KPSS } \\
\text { Klabin }\end{array}$ & \multicolumn{6}{|c|}{ Klabin } \\
\hline $\mathrm{ADF}$ & $\begin{array}{c}-1.170585 \\
(0.6456)\end{array}$ & $\begin{array}{c}-4.303427 \\
(0.0099)\end{array}$ & $\begin{array}{c}-0.821120 \\
(0.7721)\end{array}$ & $\begin{array}{c}-2.977858 \\
(0.0710)\end{array}$ & $\begin{array}{c}-6.016956 \\
(0.0007)\end{array}$ & $\begin{array}{c}-7.287059 \\
(0.0002)\end{array}$ \\
\hline $\mathrm{PP}$ & $\begin{array}{c}-1.170585 \\
(0.6456)\end{array}$ & $\begin{array}{c}-4.360585 \\
(0.0091)\end{array}$ & $\begin{array}{c}-0.199860 \\
(0.9122)\end{array}$ & $\begin{array}{c}-3.788460 \\
(0.0211)\end{array}$ & $\begin{array}{c}-6.679081 \\
(0.0003)\end{array}$ & $\begin{array}{c}-16.57752 \\
(0.0000)\end{array}$ \\
\hline KPSS & 0.435389 & 0.500000 & 0.469824 & 0.500000 & 0.500000 & 0.267931 \\
\hline \multicolumn{7}{|c|}{ Lojas Americanas } \\
\hline $\mathrm{ADF}$ & $\begin{array}{c}2.025097 \\
(0.9989) \\
\end{array}$ & $\begin{array}{c}-1.281209 \\
(0.5813) \\
\end{array}$ & $\begin{array}{c}3.677272 \\
(1.0000)\end{array}$ & $\begin{array}{c}0.699829 \\
(0.9815)\end{array}$ & $\begin{array}{c}-2.170033 \\
(0.2259)\end{array}$ & $\begin{array}{c}-2.246566 \\
(0.2036)\end{array}$ \\
\hline $\mathrm{PP}$ & $\begin{array}{c}-0.908546 \\
(0.7445)\end{array}$ & $\begin{array}{c}-7.646475 \\
(0.0001)\end{array}$ & $\begin{array}{l}1.215927 \\
(0.9954) \\
\end{array}$ & $\begin{array}{c}-3.426862 \\
(0.0363)\end{array}$ & $\begin{array}{c}-1.091854 \\
(0.6779)\end{array}$ & $\begin{array}{c}-2.246566 \\
(0.2036)\end{array}$ \\
\hline KPSS & 0.498068 & 0.500000 & 0.464405 & 0.344419 & 0.140112 & 0.223693 \\
\hline \multicolumn{7}{|c|}{ Mahle-Metal Leve } \\
\hline $\mathrm{ADF}$ & $\begin{array}{c}-3.776618 \\
(0.0215)\end{array}$ & $\begin{array}{c}-4.236687 \\
(0.0128)\end{array}$ & $\begin{array}{c}-2.603701 \\
(0.1210)\end{array}$ & $\begin{array}{c}-3.839925 \\
(0.0221)\end{array}$ & $\begin{array}{c}-2.650387 \\
(0.1154)\end{array}$ & $\begin{array}{c}-2.662761 \\
(0.1133)\end{array}$ \\
\hline PP & $\begin{array}{c}-6.636374 \\
(0.0003)\end{array}$ & $\begin{array}{c}-10.26479 \\
(0.0000)\end{array}$ & $\begin{array}{c}-2.595121 \\
(0.1225)\end{array}$ & $\begin{array}{c}-15.28336 \\
(0.0000)\end{array}$ & $\begin{array}{c}-1.772019 \\
(0.3729)\end{array}$ & $\begin{array}{c}-2.655851 \\
(0.1145)\end{array}$ \\
\hline KPSS & 0.425310 & 0.361283 & 0.486232 & 0.500000 & 0.281135 & 0.454545 \\
\hline
\end{tabular}




\section{Appendix G}

Table 11. Unit Root Tests

\begin{tabular}{|c|c|c|c|c|c|c|}
\hline Company & M.V. & $\Delta$ M.V. & B.V. & $\Delta$ B.V. & A.E. & $\Delta$ A.E. \\
\hline \multicolumn{7}{|l|}{ Natura } \\
\hline $\mathrm{ADF}$ & $\begin{array}{c}-1.904499 \\
(0.3184)\end{array}$ & $\begin{array}{c}-3.776759 \\
(0.0215)\end{array}$ & $\begin{array}{c}-1.577718 \\
(0.4599) \\
\end{array}$ & $\begin{array}{c}-2.374826 \\
(0.1704)\end{array}$ & $\begin{array}{c}-1.372435 \\
(0.5518)\end{array}$ & $\begin{array}{c}-0.751663 \\
(0.7882) \\
\end{array}$ \\
\hline PP & $\begin{array}{c}-1.904499 \\
(0.3184) \\
\end{array}$ & $\begin{array}{c}-3.776759 \\
(0.0215) \\
\end{array}$ & $\begin{array}{c}-1.571829 \\
(0.4627) \\
\end{array}$ & $\begin{array}{c}-2.374826 \\
(0.1704) \\
\end{array}$ & $\begin{array}{c}-1.199649 \\
(0.6333) \\
\end{array}$ & $\begin{array}{c}-0.751663 \\
(0.7882) \\
\end{array}$ \\
\hline KPSS & 0.163809 & 0.228187 & 0.361380 & 0.176413 & 0.145645 & 0.370210 \\
\hline \multicolumn{7}{|c|}{$\begin{array}{l}\text { Cia Brasileira de } \\
\text { Distribuição }\end{array}$} \\
\hline $\mathrm{ADF}$ & $\begin{array}{l}-1.550466 \\
(0.4726)\end{array}$ & $\begin{array}{c}-2.513085 \\
(0.1431)\end{array}$ & $\begin{array}{c}-0.548877 \\
(0.8451)\end{array}$ & $\begin{array}{c}-1.897672 \\
(0.3200)\end{array}$ & $\begin{array}{c}-0.013022 \\
(0.9372)\end{array}$ & $\begin{array}{c}-2.492891 \\
(0.1446)\end{array}$ \\
\hline PP & $\begin{array}{c}-1.539282 \\
(0.4777)\end{array}$ & $\begin{array}{l}-2.818706 \\
(0.0900)\end{array}$ & $\begin{array}{c}-0.577523 \\
(0.8383)\end{array}$ & $\begin{array}{c}-1.675858 \\
(0.4126)\end{array}$ & $\begin{array}{c}-0.195754 \\
(0.9128)\end{array}$ & $\begin{array}{c}-2.480814 \\
(0.1471)\end{array}$ \\
\hline KPSS & 0.298176 & 0.220938 & 0.475739 & 0.154771 & 0.265119 & 0.366236 \\
\hline \multicolumn{7}{|l|}{ Petrobras } \\
\hline $\mathrm{ADF}$ & $\begin{array}{c}-0.808972 \\
(0.7714) \\
\end{array}$ & $\begin{array}{c}-4.813707 \\
(0.0048) \\
\end{array}$ & $\begin{array}{c}-1.755207 \\
(0.3802) \\
\end{array}$ & $\begin{array}{c}-2.797290 \\
(0.0928)\end{array}$ & $\begin{array}{c}1.650810 \\
(0.9977) \\
\end{array}$ & $\begin{array}{c}-0.159350 \\
(0.9079) \\
\end{array}$ \\
\hline PP & $\begin{array}{c}-1.839022 \\
(0.3450) \\
\end{array}$ & $\begin{array}{c}-4.813707 \\
(0.0048) \\
\end{array}$ & $\begin{array}{c}-1.754616 \\
(0.3804) \\
\end{array}$ & $\begin{array}{c}-2.797290 \\
(0.0928) \\
\end{array}$ & $\begin{array}{c}-0.474464 \\
(0.8620) \\
\end{array}$ & $\begin{array}{c}-1.542532 \\
(0.4727) \\
\end{array}$ \\
\hline KPSS & 0.340074 & 0.184701 & 0.372239 & 0.270403 & 0.430615 & 0.500000 \\
\hline \multicolumn{7}{|l|}{ Dimed } \\
\hline $\mathrm{ADF}$ & $\begin{array}{l}1.155564 \\
(0.9947)\end{array}$ & $\begin{array}{c}-1.297193 \\
(0.5861)\end{array}$ & $\begin{array}{l}3.439947 \\
(1.0000)\end{array}$ & $\begin{array}{c}-1.133962 \\
(0.6563)\end{array}$ & $\begin{array}{c}-1.740936 \\
(0.3864)\end{array}$ & $\begin{array}{c}-3.015644 \\
(0.0672)\end{array}$ \\
\hline PP & $\begin{array}{l}4.196683 \\
(1.0000)\end{array}$ & $\begin{array}{l}-1.026385 \\
(0.6986)\end{array}$ & $\begin{array}{c}2.962259 \\
(0.9999)\end{array}$ & $\begin{array}{c}-0.823359 \\
(0.7670)\end{array}$ & $\begin{array}{c}-1.768287 \\
(0.3745)\end{array}$ & $\begin{array}{c}-3.012821 \\
(0.0675)\end{array}$ \\
\hline KPSS & 0.501354 & 0.330129 & 0.496393 & 0.403842 & 0.241903 & 0.233982 \\
\hline \multicolumn{7}{|l|}{ Marcopolo } \\
\hline $\mathrm{ADF}$ & $\begin{array}{c}-1.660868 \\
(0.4219) \\
\end{array}$ & $\begin{array}{c}-2.713820 \\
(0.1051) \\
\end{array}$ & $\begin{array}{l}1.452152 \\
(0.9973) \\
\end{array}$ & $\begin{array}{c}-2.336112 \\
(0.1798) \\
\end{array}$ & $\begin{array}{c}-2.115113 \\
(0.2429) \\
\end{array}$ & $\begin{array}{c}-2.288312 \\
(0.1923) \\
\end{array}$ \\
\hline PP & $\begin{array}{c}-1.660868 \\
(0.4219) \\
\end{array}$ & $\begin{array}{c}-2.713820 \\
(0.1051) \\
\end{array}$ & $\begin{array}{c}2.043007 \\
(0.9993) \\
\end{array}$ & $\begin{array}{c}-2.277662 \\
(0.1951) \\
\end{array}$ & $\begin{array}{c}-1.463655 \\
(0.5133) \\
\end{array}$ & $\begin{array}{c}-2.294399 \\
(0.1907) \\
\end{array}$ \\
\hline KPSS & 0.262836 & 0.155384 & 0.506941 & 0.330873 & 0.161248 & 0.234894 \\
\hline
\end{tabular}

\section{Appendix G}

Table 11. Unit Root Tests

\begin{tabular}{|c|c|c|c|c|c|c|}
\hline Company & M.V. & $\Delta \mathrm{M} . \mathrm{V}$. & B.V. & $\Delta \mathrm{B} . \mathrm{V}$. & A.E. & $\Delta$ A.E. \\
\hline \multicolumn{7}{|l|}{ Randon } \\
\hline $\mathrm{ADF}$ & $\begin{array}{c}-2.292907 \\
(0.1898)\end{array}$ & $\begin{array}{c}-4.215062 \\
(0.0113)\end{array}$ & $\begin{array}{c}-1.916446 \\
(0.3137)\end{array}$ & $\begin{array}{c}-0.216375 \\
(0.9032)\end{array}$ & $\begin{array}{c}2.720295 \\
(0.9997)\end{array}$ & $\begin{array}{c}-0.082514 \\
(0.9195)\end{array}$ \\
\hline PP & $\begin{array}{c}-2.292907 \\
(0.1898)\end{array}$ & $\begin{array}{c}-4.473734 \\
(0.0078)\end{array}$ & $\begin{array}{c}-1.831372 \\
(0.3481)\end{array}$ & $\begin{array}{c}-1.178115 \\
(0.6379)\end{array}$ & $\begin{array}{c}-0.695415 \\
(0.8081)\end{array}$ & $\begin{array}{c}-4.502385 \\
(0.0075)\end{array}$ \\
\hline KPSS & 0.200031 & 0.500000 & 0.378116 & 0.370734 & 0.470007 & 0.454545 \\
\hline \multicolumn{7}{|l|}{ Sanepar } \\
\hline $\mathrm{ADF}$ & $\begin{array}{c}0.451243 \\
(0.9736)\end{array}$ & $\begin{array}{c}-5.046360 \\
(0.0035)\end{array}$ & $\begin{array}{c}3.065244 \\
(0.9999)\end{array}$ & $\begin{array}{c}-0.041941 \\
(0.9288)\end{array}$ & $\begin{array}{c}-1.810158 \\
(0.3569)\end{array}$ & $\begin{array}{c}-3.032564 \\
(0.0655)\end{array}$ \\
\hline PP & $\begin{array}{c}-0.428017 \\
(0.8718) \\
\end{array}$ & $\begin{array}{c}-5.076144 \\
(0.0034)\end{array}$ & $\begin{array}{l}1.923122 \\
(0.9991)\end{array}$ & $\begin{array}{c}-2.406724 \\
(0.1631) \\
\end{array}$ & $\begin{array}{c}-1.748998 \\
(0.3829) \\
\end{array}$ & $\begin{array}{c}-3.259486 \\
(0.0466) \\
\end{array}$ \\
\hline KPSS & 0.484994 & 0.281444 & 0.408117 & 0.384907 & 0.328376 & 0.454545 \\
\hline \multicolumn{7}{|c|}{$\begin{array}{c}\text { Cia San. Basico Est. São } \\
\text { Paulo }\end{array}$} \\
\hline $\mathrm{ADF}$ & $\begin{array}{c}-0.621783 \\
(0.8182)\end{array}$ & $\begin{array}{c}-3.851210 \\
(0.0218)\end{array}$ & $\begin{array}{c}0.998010 \\
(0.9911)\end{array}$ & $\begin{array}{c}-4.979860 \\
(0.0039)\end{array}$ & $\begin{array}{c}-3.021642 \\
(0.0666)\end{array}$ & $\begin{array}{c}-3.494762 \\
(0.0359)\end{array}$ \\
\hline PP & $\begin{array}{c}-0.919015 \\
(0.7410)\end{array}$ & $\begin{array}{c}-2.475315 \\
(0.1482)\end{array}$ & $\begin{array}{l}1.022893 \\
(0.9928)\end{array}$ & $\begin{array}{c}-6.524010 \\
(0.0005)\end{array}$ & $\begin{array}{c}-3.076265 \\
(0.0584)\end{array}$ & $\begin{array}{c}-2.091076 \\
(0.2506)\end{array}$ \\
\hline KPSS & 0.461429 & 0.500000 & 0.506747 & 0.500000 & 0.179216 & 0.500000 \\
\hline \multicolumn{7}{|l|}{ Saraiva } \\
\hline $\mathrm{ADF}$ & $\begin{array}{l}1.143407 \\
(0.9934) \\
\end{array}$ & $\begin{array}{c}-0.375194 \\
(0.8696) \\
\end{array}$ & $\begin{array}{c}-2.858921 \\
(0.0818) \\
\end{array}$ & $\begin{array}{c}-1.672840 \\
(0.4139) \\
\end{array}$ & $\begin{array}{l}1.995057 \\
(0.9989) \\
\end{array}$ & $\begin{array}{c}-1.174895 \\
(0.6270) \\
\end{array}$ \\
\hline PP & $\begin{array}{l}-1.709532 \\
(0.4002)\end{array}$ & $\begin{array}{l}-5.568936 \\
(0.0018)\end{array}$ & $\begin{array}{l}-6.250303 \\
(0.0005)\end{array}$ & $\begin{array}{c}-1.450825 \\
(0.5154)\end{array}$ & $\begin{array}{c}-1.556501 \\
(0.4697) \\
\end{array}$ & $\begin{array}{c}-6.002474 \\
(0.0010)\end{array}$ \\
\hline KPSS & 0.337437 & 0.500000 & 0.468820 & 0.528603 & 0.449937 & 0.500000 \\
\hline \multicolumn{7}{|l|}{ CTEEP } \\
\hline $\mathrm{ADF}$ & $\begin{array}{c}-1.840373 \\
(0.3429) \\
\end{array}$ & $\begin{array}{c}-1.534389 \\
(0.4765) \\
\end{array}$ & $\begin{array}{r}1.273789 \\
(0.9960) \\
\end{array}$ & $\begin{array}{c}-0.446196 \\
(0.8645) \\
\end{array}$ & $\begin{array}{c}-2.574057 \\
(0.1318) \\
\end{array}$ & $\begin{array}{c}-1.229873 \\
(0.6042) \\
\end{array}$ \\
\hline PP & $\begin{array}{c}-1.090793 \\
(0.6783)\end{array}$ & $\begin{array}{c}-1.534389 \\
(0.4765)\end{array}$ & $\begin{array}{l}2.145915 \\
(0.9994)\end{array}$ & $\begin{array}{c}-0.446196 \\
(0.8645)\end{array}$ & $\begin{array}{l}1.803784 \\
(0.9988)\end{array}$ & $\begin{array}{c}-1.337400 \\
(0.5678)\end{array}$ \\
\hline KPSS & 0.269951 & 0.155885 & 0.474223 & 0.307120 & 0.272572 & 0.240753 \\
\hline
\end{tabular}




\section{Appendix G}

Table 11. Unit Root Tests

\begin{tabular}{|c|c|c|c|c|c|c|}
\hline Company & M.V. & $\Delta \mathrm{M} . \mathrm{V}$. & B.V. & $\Delta$ B.V. & A.E. & $\Delta$ A.E. \\
\hline \multicolumn{7}{|l|}{ Ultrapar } \\
\hline $\mathrm{ADF}$ & $\begin{array}{c}-1.833979 \\
(0.3471)\end{array}$ & $\begin{array}{c}-3.776187 \\
(0.0215)\end{array}$ & $\begin{array}{c}-3.242639 \\
(0.0512)\end{array}$ & $\begin{array}{c}-2.955672 \\
(0.0734)\end{array}$ & $\begin{array}{c}-1.738014 \\
(0.3877)\end{array}$ & $\begin{array}{c}-3.392023 \\
(0.0415)\end{array}$ \\
\hline PP & $\begin{array}{c}-1.741973 \\
(0.3860)\end{array}$ & $\begin{array}{c}-5.987213 \\
(0.0010)\end{array}$ & $\begin{array}{c}-1.966541 \\
(0.2947)\end{array}$ & $\begin{array}{c}-2.955672 \\
(0.0734)\end{array}$ & $\begin{array}{c}-1.628122 \\
(0.4368)\end{array}$ & $\begin{array}{c}-4.925141 \\
(0.0042)\end{array}$ \\
\hline KPSS & 0.503172 & 0.500000 & 0.101126 & 0.108078 & 0.342157 & 0.500000 \\
\hline \multicolumn{7}{|l|}{ Unipar } \\
\hline $\mathrm{ADF}$ & $\begin{array}{c}-1.089618 \\
(0.6742) \\
\end{array}$ & $\begin{array}{c}-6.285580 \\
(0.0007) \\
\end{array}$ & $\begin{array}{c}-1.843388 \\
(0.3432)\end{array}$ & $\begin{array}{c}-3.837072 \\
(0.0197)\end{array}$ & $\begin{array}{c}-2.371125 \\
(0.1697) \\
\end{array}$ & $\begin{array}{c}-3.845426 \\
(0.0194) \\
\end{array}$ \\
\hline PP & $\begin{array}{c}-1.796957 \\
(0.3624)\end{array}$ & $\begin{array}{c}-6.285580 \\
(0.0007)\end{array}$ & $\begin{array}{c}-1.817830 \\
(0.3537)\end{array}$ & $\begin{array}{c}-3.837072 \\
(0.0197)\end{array}$ & $\begin{array}{c}-2.384463 \\
(0.1665)\end{array}$ & $\begin{array}{c}-5.864156 \\
(0.0012) \\
\end{array}$ \\
\hline KPSS & 0.402091 & 0.184211 & 0.223684 & 0.093604 & 0.207003 & 0.500000 \\
\hline \multicolumn{7}{|l|}{ Usiminas } \\
\hline $\mathrm{ADF}$ & $\begin{array}{c}1.052278 \\
(0.9921)\end{array}$ & $\begin{array}{c}-6.489622 \\
(0.0008)\end{array}$ & $\begin{array}{c}-1.044255 \\
(0.6918)\end{array}$ & $\begin{array}{c}2.459846 \\
(0.9994)\end{array}$ & $\begin{array}{c}-0.080813 \\
(0.9237)\end{array}$ & $\begin{array}{c}-6.038628 \\
(0.0010) \\
\end{array}$ \\
\hline PP & $\begin{array}{c}-1.592109 \\
(0.4532)\end{array}$ & $\begin{array}{c}-6.271782 \\
(0.0007)\end{array}$ & $\begin{array}{c}-1.580744 \\
(0.4585)\end{array}$ & $\begin{array}{c}1.577226 \\
(0.9977) \\
\end{array}$ & $\begin{array}{c}-1.673361 \\
(0.4163) \\
\end{array}$ & $\begin{array}{c}-12.89987 \\
(0.0000) \\
\end{array}$ \\
\hline KPSS & 0.377377 & 0.500000 & 0.257453 & 0.514947 & 0.482328 & 0.500000 \\
\hline \multicolumn{7}{|l|}{ Vale } \\
\hline $\mathrm{ADF}$ & $\begin{array}{c}-2.334674 \\
(0.1787) \\
\end{array}$ & $\begin{array}{c}-4.368486 \\
(0.0090) \\
\end{array}$ & $\begin{array}{c}-2.687943 \\
(0.1125) \\
\end{array}$ & $\begin{array}{c}-0.536931 \\
(0.8393) \\
\end{array}$ & $\begin{array}{c}-1.891095 \\
(0.3237) \\
\end{array}$ & $\begin{array}{c}-4.247406 \\
(0.0107) \\
\end{array}$ \\
\hline PP & $\begin{array}{c}-2.330644 \\
(0.1798)\end{array}$ & $\begin{array}{c}-4.696887 \\
(0.0057)\end{array}$ & $\begin{array}{c}-1.513887 \\
(0.4896)\end{array}$ & $\begin{array}{c}-3.275301 \\
(0.0455)\end{array}$ & $\begin{array}{c}-1.891095 \\
(0.3237) \\
\end{array}$ & $\begin{array}{c}-4.263987 \\
(0.0105) \\
\end{array}$ \\
\hline KPSS & 0.248069 & 0.500000 & 0.427512 & 0.129302 & 0.351666 & 0.310753 \\
\hline \multicolumn{7}{|l|}{ Weg } \\
\hline $\mathrm{ADF}$ & $\begin{array}{c}-1.134561 \\
(0.6606) \\
\end{array}$ & $\begin{array}{c}-3.732811 \\
(0.0230) \\
\end{array}$ & $\begin{array}{c}0.594900 \\
(0.9815) \\
\end{array}$ & $\begin{array}{c}-2.801929 \\
(0.0999) \\
\end{array}$ & $\begin{array}{c}-2.350002 \\
(0.1749) \\
\end{array}$ & $\begin{array}{c}-4.873809 \\
(0.0045) \\
\end{array}$ \\
\hline PP & $\begin{array}{c}-1.215729 \\
(0.6264)\end{array}$ & $\begin{array}{c}-3.732811 \\
(0.0230)\end{array}$ & $\begin{array}{c}0.697209 \\
(0.9852) \\
\end{array}$ & $\begin{array}{c}-2.606500 \\
(0.1230)\end{array}$ & $\begin{array}{c}-2.375386 \\
(0.1687) \\
\end{array}$ & $\begin{array}{c}-4.873809 \\
(0.0045) \\
\end{array}$ \\
\hline KPSS & 0.386416 & 0.500000 & 0.451160 & 0.324847 & 0.174459 & 0.500000 \\
\hline
\end{tabular}

\section{Appendix $\mathbf{H}$}

Table 12. Johansen Cointegration Test

\begin{tabular}{|c|c|c|}
\hline Company & Trace Statistics & $\begin{array}{c}\text { Statistics of max. } \\
\text { eigenvalue }\end{array}$ \\
\hline Aes Elpa & $24.82044(0.1679)$ & $18.18337(0.1231)$ \\
\hline Alpargatas & $92.01281(0.0000)$ & $78.90553(0.0000)$ \\
\hline Bradespar & $82.76503(0.0000)$ & $50.16138(0.0000)$ \\
\hline BRF & $33.49658(0.0179)$ & $20.53004(0.0605)$ \\
\hline Braskem & $33.98762(0.0155)$ & $24.76460(0.0147)$ \\
\hline Grazziotin & $64.25523(0.0000)$ & $56.65381(0.0000)$ \\
\hline Centrais Elet. De Santa Catarina & $89.23956(0.0000)$ & $74.15752(0.0000)$ \\
\hline $\begin{array}{c}\text { Copel } \\
\end{array}$ & $72.50663(0.0000)$ & $57.91649(0.0000)$ \\
\hline Cia Siderurgica Nacional & $42.52996(0.0010)$ & $29.22302(0.0029)$ \\
\hline Coteminas & $72.93834(0.0000)$ & $64.52437(0.0000)$ \\
\hline Diagnosticos da America & $75.13967(0.0000)$ & $57.27514(0.0000)$ \\
\hline Embraer & $40.96117(0.0017)$ & $20.40577(0.0629)$ \\
\hline Ferbasa & $33.88635(0.0160)$ & $25.45416(0.0116)$ \\
\hline Fibria Celulose & $71.58097(0.0000)$ & $58.31695(0.0000)$ \\
\hline Metalurgica Gerdau & $51.00015(0.0001)$ & $35.22744(0.0003)$ \\
\hline Cia Saneamento Basico Est. São Paulo & $114.5957(0.0000)$ & $94.28435(0.0000)$ \\
\hline Ultrapar & $51.71293(0.0000)$ & $39.87272(0.0001)$ \\
\hline Unipar & $43.09374(0.0009)$ & $30.53889(0.0018)$ \\
\hline Vale & $84.63675(0.0000)$ & $54.66800(0.0000)$ \\
\hline Weg & $30.87306(0.0375)$ & $22.42303(0.0327)$ \\
\hline
\end{tabular}




\section{Appndix I}

Table 13. DOLS Estimation

\begin{tabular}{ccc}
\hline Company & Book Value & Abnormal Earning \\
\hline Alpargatas & $1970.230(0.0002)$ & $20647.22(0.0028)$ \\
\hline Bradespar & $878.5743(0.1539)$ & $1378.139(0.6129)$ \\
\hline BRF & $2799.405(0.0000)$ & $-668.0131(0.8814)$ \\
\hline Braskem & $1252.129(0.0003)$ & $1706.267(0.1224)$ \\
\hline Grazziotin & $572.5187(0.0088)$ & $9434.379(0.0147)$ \\
\hline Centrais Elet. De Santa Catarina & $645.9889(0.0281)$ & $3441.777(0.4058)$ \\
\hline Copel & $717.3819(0.0009)$ & $6437.192(0.0253)$ \\
\hline Cia Siderurgica Nacional & $2644.542(0.0001)$ & $3148.014(0.0426)$ \\
\hline Coteminas & $517.5300(0.0577)$ & $1176.861(0.4203)$ \\
\hline Diagnosticos da America & $3550.855(0.0052)$ & $19782.15(0.0841)$ \\
\hline Embraer & $1644.834(0.0001)$ & $6342.722(0.1222)$ \\
\hline Ferbasa & $468.7512(0.0781)$ & $-638.2178(0.7879)$ \\
\hline Fibria Celulose & $1616.227(0.0000)$ & $4150.956(0.0165)$ \\
\hline Metalurgica Gerdau & $481.1901(0.0002)$ & $1981.749(0.0505)$ \\
\hline Uia Saneamento Basico Est. São Paulo & $1021.283(0.0000)$ & $2921.657(0.2198)$ \\
\hline Unipar & $2233.150(0.0000)$ & $24304.51(0.0004)$ \\
\hline Vale & $845.1980(0.0008)$ & $-540.5997(0.4504)$ \\
\hline Weg & $1277.681(0.0018)$ & $2317.005(0.1002)$ \\
\hline
\end{tabular}

\section{Copyrights}

Copyright for this article is retained by the author(s), with first publication rights granted to the journal.

This is an open-access article distributed under the terms and conditions of the Creative Commons Attribution license which permits unrestricted use, distribution, and reproduction in any medium, provided the original work is properly cited. 